\title{
Management and Medical Therapy of Mild Hypercortisolism
}

\author{
Vittoria Favero ${ }^{1}$, Arianna Cremaschi ${ }^{1}$, Alberto Falchetti ${ }^{2} \mathbb{D}$, Agostino Gaudio $^{3} \mathbb{D}$, Luigi Gennari ${ }^{4}$, \\ Alfredo Scillitani ${ }^{5}$, Fabio Vescini ${ }^{6}$, Valentina Morelli ${ }^{7}\left(\mathbb{D}\right.$, Carmen Aresta $^{2, *}+{ }^{(D)}$ and Iacopo Chiodini ${ }^{1,2}(\mathbb{D})$
}

1 Department of Medical Biotechnology and Translational Medicine, University of Milan, 20133 Milan, Italy; vittoria.favero@unimi.it (V.F.); arianna.cremaschi@unimi.it (A.C.); iacopo.chiodini@unimi.it (I.C.)

2 Department of Endocrine and Metabolic Diseases, IRCCS, Istituto Auxologico Italiano, 20149 Milan, Italy; a.falchetti@auxologico.it

3 Department of Clinical and Experimental Medicine, University of Catania, 95123 Catania, Italy; agostino.gaudio@unict.it

4 Department of Medicine, Surgery and Neurosciences, University of Siena, 53100 Siena, Italy; luigi.gennari@unisi.it

5 Unit of Endocrinology and Diabetology “Casa Sollievo della Sofferenza” Hospital, IRCCS, 71013 San Giovanni Rotondo (FG), Italy; alfredo.scillitani@gmail.com

6 Endocrinology and Metabolism Unit, University-Hospital S. M. Misericordia of Udine, 33100 Udine, Italy; vescini.fabio@aoud.sanita.fvg.it

7 Unit of Endocrinology, Fondazione IRCCS Cà Granda-Ospedale Maggiore Policlinico, 20122 Milan, Italy; valentina.morelli@policlinico.mi.it

* Correspondence: c.aresta@auxologico.it; Tel.: +39-02-61911-2738

+ Unit for Bone Metabolism Diseases and Diabetes \& Lab of Endocrine and Metabolic Research, Istituto Auxologico Italiano, IRCCS, Via Magnasco 2, 20149 Milan, Italy.

Citation: Favero, V.; Cremaschi, A.; Falchetti, A.; Gaudio, A.; Gennari, L.; Scillitani, A.; Vescini, F.; Morelli, V.; Aresta, C.; Chiodini, I. Management and Medical Therapy of Mild Hypercortisolism. Int. J. Mol. Sci. 2021, 22, 11521. https://doi.org/ $10.3390 /$ ijms 222111521

Academic Editor: Paola Marcolongo

Received: 6 October 2021

Accepted: 22 October 2021

Published: 26 October 2021

Publisher's Note: MDPI stays neutral with regard to jurisdictional claims in published maps and institutional affiliations.

Copyright: (c) 2021 by the authors. Licensee MDPI, Basel, Switzerland. This article is an open access article distributed under the terms and conditions of the Creative Commons Attribution (CC BY) license (https:/ / creativecommons.org/licenses/by/ $4.0 /)$.
Abstract: Mild hypercortisolism (mHC) is defined as an excessive cortisol secretion, without the classical manifestations of clinically overt Cushing's syndrome. This condition increases the risk of bone fragility, neuropsychological alterations, hypertension, diabetes, cardiovascular events and mortality. At variance with Cushing's syndrome, $\mathrm{mHC}$ is not rare, with it estimated to be present in up to $2 \%$ of individuals older than 60 years, with higher prevalence (up to $10 \%$ ) in individuals with uncontrolled hypertension and/or diabetes or with unexplainable bone fragility. Measuring cortisol after a $1 \mathrm{mg}$ overnight dexamethasone suppression test is the first-line test for searching for $\mathrm{mHC}$, and the degree of cortisol suppression is associated with the presence of cortisol-related consequences and mortality. Among the additional tests used for diagnosing $\mathrm{mHC}$ in doubtful cases, the basal morning plasma adrenocorticotroph hormone, 24-h urinary free cortisol and/or late-night salivary cortisol could be measured, particularly in patients with possible cortisol-related complications, such as hypertension and diabetes. Surgery is considered as a possible therapeutic option in patients with munilateral adrenal incidentalomas and $\mathrm{mHC}$ since it improves diabetes and hypertension and reduces the fracture risk. In patients with $\mathrm{mHC}$ and bilateral adrenal adenomas, in whom surgery would lead to persistent hypocortisolism, and in patients refusing surgery or in whom surgery is not feasible, medical therapy is needed. Currently, promising though scarce data have been provided on the possible use of pituitary-directed agents, such as the multi-ligand somatostatin analog pasireotide or the dopamine agonist cabergoline for the-nowadays-rare patients with pituitary $\mathrm{mHC}$. In the more frequently adrenal $\mathrm{mHC}$, encouraging data are available for metyrapone, a steroidogenesis inhibitor acting mainly against the adrenal 11- $\beta$ hydroxylase, while data on osilodrostat and levoketoconazole, other new steroidogenesis inhibitors, are still needed in patients with $\mathrm{mHC}$. Finally, on the basis of promising data with mifepristone, a non-selective glucocorticoid receptor antagonist, in patients with mild cortisol hypersecretion, a randomized placebo-controlled study is ongoing for assessing the efficacy and safety of relacorilant, a selective glucocorticoid receptor antagonist, for patients with mild adrenal hypercortisolism and diabetes mellitus/impaired glucose tolerance and/or uncontrolled systolic hypertension.

Keywords: hypercortisolism; adrenal steroidogenesis; glucocorticoid receptor; 11 betahydroxysteroid dehydrogenase; somatostatin; dopamine 


\section{Introduction}

Mild hypercortisolism ( $\mathrm{mHC}$ ), also defined as subclinical hypercortisolism, less severe hypercortisolism or subclinical Cushing syndrome (CS), is a condition of excessive cortisol secretion, without the specific symptoms and manifestations of clinically overt CS (i.e., proximal muscle weakness, facial plethora, easy bruising, purple striae) $[1,2]$. Despite the lack of typical signs and symptoms and the absence of severe cortisol excess, $\mathrm{mHC}$ has been associated with bone fragility, mood alterations, hypertension, alterations in glucose and lipid metabolism, increased cardiovascular risk and mortality [3-13]. At variance, patients with $\mathrm{mHC}$ may present with features that are common in the general population and less discriminatory for the presence of a cortisol excess, such as a dorso-cervical fat pad ("buffalo hump"), facial fullness, obesity, supraclavicular fullness, thin skin, peripheral edema, acne, hirsutism and poor skin healing. In some patients, mHC may be also completely hidden, and, in this case, it has been called "hidden hypercortisolism" (HidHyCo). Thus, the difference between $\mathrm{mHC}$ and HidHyCo is not trivial, as in the former condition, some symptoms may push the patient to seek medical advice, while the latter condition may be found only casually [13].

Indeed, a HidHyCo condition is detectable in about $5-30 \%$ of patients with adrenal incidentalomas, which are adrenal lesions detected by imaging studies carried out for reasons other than the suspicion of adrenal diseases [14], with a particularly high prevalence in patients with bilateral forms [15-17]. As adrenal incidentalomas are thought to be present in up to $7 \%$ of individuals above 60 years of age, a condition of HidHyCo is estimated to be present in $0.8-2 \%$ of the elderly population, a prevalence, thus, definitely higher than that reported in for CS [18,19].

At variance with the numerous data in patients with adrenal incidentalomas, there are scarce data on the frequency of adrenocorticotropin (ACTH)-dependent $\mathrm{mHC}$ and, in particular, HidHyCo. In a study by Toini and coauthors on patients with pituitary incidentalomas, the prevalence of HidHyCo has been found to be about 5\% [20]. Finally, the overall prevalence of HidHyCo seems to be more prevalent (up to $10 \%$ ) in highrisk populations such as in diabetic and/or hypertensive patients and individuals with unexplainable bone fragility $[13,21]$.

In patients with unilateral adrenal incidentaloma and $\mathrm{mHC}$, the surgical removal of the adrenal mass is suggested by some authors in the presence of consequences of hypercortisolism, since several data show the improvement of T2D and hypertension and the reduction of fracture risk after recovery from cortisol excess [22,23]. In patients with bilateral adrenal incidentalomas and $\mathrm{mHC}$, the complete remission of cortisol hypersecretion can be achieved only performing a bilateral adrenalectomy, which, however, leads to persistent hypocortisolism and a consequent need for lifelong glucocorticoid (GC) replacement therapy [24]. In order to avoid bilateral adrenalectomy, an initial approach with unilateral adrenalectomy has been suggested, aiming to remove the larger and/or more hypersecreting adrenal mass. However, this approach is burdened with a high number of relapses of hypercortisolism [25]. The surgical treatment (i.e., removal of the pituitary adenoma and/or pituitary surgical exploration) in patients with $\mathrm{mHC}$ of pituitary origin has never been investigated. In these patients, the treatment of comorbidities possibly related to cortisol excess (i.e., mental health deterioration, osteoporosis, diabetes and hypertension) rather than curing the underlying disease is the only available approach.

On the basis of these considerations, medical therapy of $\mathrm{mHC}$ in patients not applicable for surgery due to the presence of contraindications or the patient's refusal has been advocated [26]. In this review, we aimed to summarize the available data regarding the medical treatment of $\mathrm{mHC}$, with a particular focus on the molecular pathways that are targeted by the currently available drugs, starting with a brief summary of the criteria for diagnosing $\mathrm{mHC}$. For the sake of simplicity, and since the available studies included both HidHyCo and mHC patients, in the present work we refer only to the latter condition. 


\section{Diagnosis of Mild Hypercortisolism}

There is no consensus yet on the clinical and/or biochemical criteria for diagnosing mHC [27], and, of importance, most of the literature focuses on the screening for mHC of adrenal origin only. In the diagnostic algorithm of adrenal masses, many guidelines recommend the use of the $1 \mathrm{mg}$ overnight dexamethasone suppression test (1 mg-DST), due to its better sensitivity in screening for this condition [19,24,28-30]. It must be noted that cortisol secretion is a continuum from completely normal to clearly increased levels, and it is highly variable in the same individual. For this reason, evaluating the degree of cortisol secretion should be conducted by considering cortisol levels after $1 \mathrm{mg}$-DST as a continuous variable, rather than a categorical one [27]. For, at least partially, satisfying this need, other guidelines distinguish different cut-offs of cortisol levels after $1 \mathrm{mg}$-DST with cortisol levels after $1 \mathrm{mg}$-DST between 50 and $138 \mathrm{nmol} / \mathrm{L}(1.9-5.0 \mu \mathrm{g} / \mathrm{dL})$ or above $138 \mathrm{nmol} / \mathrm{L}(>5.0 \mu \mathrm{g} / \mathrm{dL})$ indicating either "possible autonomous cortisol secretion" or "confirmed autonomous cortisol secretion", respectively [14].

In AI patients, several studies have shown a correlation between cortisol levels after $1 \mathrm{mg}$-DST and mortality risk, regardless of age and the presence of diabetes and hypertension $[6,8,10]$. A recent Swedish study not only confirmed these findings, but also showed that the relationship between cortisol levels after $1 \mathrm{mg}$-DST, mortality and cardiovascular disease in AI patients and $\mathrm{mHC}$ is linear up to cortisol levels after $1 \mathrm{mg}$-DST of $200 \mathrm{nmol} / \mathrm{L}$ $(7.3 \mu \mathrm{g} / \mathrm{dL})$ and that a plasma cortisol level of $83 \mathrm{nmol} / \mathrm{L}(3.0 \mu \mathrm{g} / \mathrm{dL})$ or higher is associated with a 2- to 3-fold increased mortality risk. If on one hand cortisol after $1 \mathrm{mg}$-DST, whatever the cut-off, is a highly sensitive diagnostic tool, on the other hand, it is offset by low specificity. Indeed, some authors suggest that if we used cortisol after $1 \mathrm{mg}$-DST at a cut off of $50 \mathrm{nmol} / \mathrm{L}(1.8 \mu \mathrm{g} / \mathrm{dL})$ or of $140 \mathrm{nmol} / \mathrm{L}(5.1 \mu \mathrm{g} / \mathrm{dL})$ for diagnosing hypercortisolism, $20 \%$ and $5 \%$ of the normal population, respectively, would have an abnormal test [9].

Reporting all data regarding the different tests used for diagnosing $\mathrm{mHC}$ is beyond the scope of the present review. It only seems worth reminding here that additional biochemical tests have been studied [31]. Although none of them were convincing enough for establishing the presence of $\mathrm{mHC}$, they may be used to improve the specificity of the diagnostic approach and to assess the degree of cortisol secretion [32]. Among the additional tests used for diagnosing adrenal $\mathrm{mHC}$, experts agreed on using the measurement of the basal morning plasma adrenocorticotroph hormone (ACTH), 24-h urinary free cortisol and/or late-night salivary cortisol [14], even if, for the latter, the available data are less encouraging [33].

Nowadays, more and more authors also agree on the fact that the intention of searching for HidHyCo in patients with increased probability of having $\mathrm{mHC}$, such as those with insulin-treated and/or complicated diabetes, scarcely controlled hypertension and unexplainable bone fragility, highly depends on the sensitivity of the physician rather than on the specificity of the available tests $[1,34,35]$. Therefore, increasing our awareness in suspecting HidHyCo and our skills in diagnosing $\mathrm{mHC}$ will increase the number of patients diagnosed with hypercortisolism, thus requiring appropriate management.

\section{Management of Mild Hypercortisolism}

In overt hypercortisolism of any etiology, surgical resection of the causal tumor is the treatment of choice, while other approaches, such as radiation therapy (for pituitary tumors) or medical therapy, are used when surgery is not possible or not curative [36]. The surgical options include tumor resection in pituitary-dependent hypercortisolism, unilateral adrenalectomy in adrenal hypercortisolism and resection of ACTH-secreting neuroendocrine tumors in hypercortisolism of ectopic source [37]. Bilateral adrenalectomy may be performed in patients with macronodular and micronodular adrenal hyperplasia or in patients with ACTH-dependent Cushing syndrome when a surgical cure is not feasible [37]. Monolateral adrenalectomy in patients with bilateral adrenal hyperplasia is burdened by a high rate of recurrence of hypercortisolism [38]. 
Besides the biochemical tests, the presence of possible cortisol-related comorbidities are elements to consider for addressing the treatment of choice in patients with $\mathrm{mHC}$. In patients with adrenal incidentalomas and possible $\mathrm{mHC}$, combining the use of cortisol after $1 \mathrm{mg}$-DST with additional tests and with the clinical features (i.e., presence of hypertension, obesity and diabetes) seems to reliably predict both the clinical amelioration after surgery and clinical worsening if the $\mathrm{mHC}$ is left untreated $[39,40]$. Likewise, the incidence of vertebral fractures is dramatically reduced after adrenalectomy in patients with adrenal incidentalomas and $\mathrm{mHC}$, while it reaches $50 \%$ if patients are conservatively managed [23].

Although surgery remains the preferable approach for patients with a unilateral adrenal functioning tumor, nowadays and in particular during this period of the COVID-19 pandemic, more and more patients are left untreated due to the scarce availability of hospital beds. Moreover, to date, many patients are diagnosed with bilateral adrenal lesions and in many patients, surgery is not feasible due to advanced age and the high risk of surgical complications. In this setting, medical therapy of $\mathrm{mHC}$ is advisable. Notwithstanding this urgent need, data on the efficacy and safety of the classical drugs used to cure $\mathrm{mHC}$ are still lacking [5,24]. In patients with adrenal hypercortisolism, nowadays, medical therapy includes adrenal steroidogenesis-inhibiting agents (ketoconazole, metyrapone, mitotane, etomidate) and a GC receptor (GR) blocker (mifepristone). A new steroidogenesis inhibitor has been developed and approved (osilodrostat) and another GR antagonist (relacorilant) is under clinical trial. Finally, very recently in a small study, the $11 \beta$-hydroxysteroid dehydrogenase (11BHSD) type 1 (11BHSD1) inhibitor S-707106 demonstrated an effective insulin sensitizer, anti-sarcopenic and anti-obesity effect in both CS and $\mathrm{mHC}$ patients [41].

The use of other adrenal blocker drugs, such as etomidate and mitotane, will not be discussed in this review, as they are considered unlikely to have a role in the treatment of mild forms of hypercortisolism.

The mechanism of action, dose range, adverse effect and clinical effects of the currently available drugs or possible new agents under phase III clinical trials for treating $\mathrm{mHC}$ are summarized and figuratively depicted in Figure 1 and Table 1, respectively. 


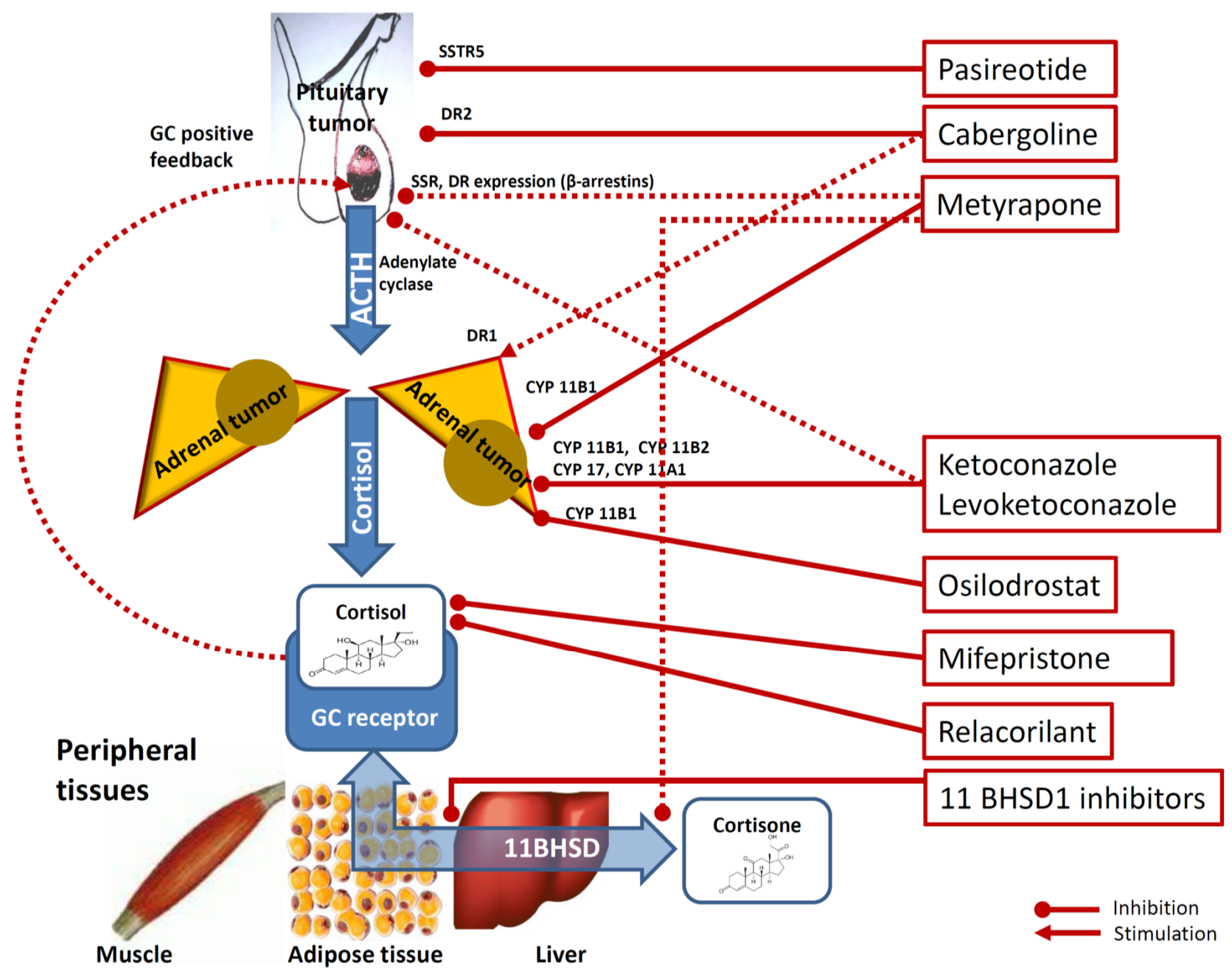

Figure 1. Mechanisms underlying the effects of medical therapy of hypercortisolism. Footnotes: Cabergoline inhibit pituitary corticotrophs via dopamine receptor type 2 (DR2). Cabergoline is also thought to exert a stimulatory role on cortisol secretion on adrenal cortex cells via DR1 dopamine receptor type 2. Pasireotide inhibits pituitary corticotrophs via somatostatine receptors type 5 (SSTR5). Metyrapone inhibits adrenal 11- $\beta$ hydroxylase and, to a lesser degree, 18hydroxylase (CYP11B1). Metyrapone is also hypothesized to reduce at the peripheral target tissues (i.e., muscle, adipocytes and liver) the conversion of cortisone into the more active cortisol via modulation of 11beta-hydroxysteroido-dehydrogenase (11BHSD) and to inhibit pituitary corticotrophs via reduction of GC-driven positive-feedback and via SSTR5 and DR2 receptors expression via the modulation of $\beta$-arrestin 1 and $\beta$-arrestin 2 expression. Ketoconazole and levoketoconazole act on the adrenal steroidogenesis via 11- $\beta$ hydroxylase (CYP11B1) inhibition, 18-hydroxylase (CYP11B2) inhibition, 20,22desmolase (CYP11A1) inhibition and on 17a-hydroxylase and 17,20-desmolase (CYP17) inhibition. Ketoconazole and levoketokonazole are also hypothesized to inhibit pituitary corticotroph inhibition by impairing adenylate cyclase activation. Osilodrostat is a steroidogenesis inhibitor acting on CYP11B1) via 11- $\beta$ hydroxylase inhibition. Mifepristone inhibits the peripheral effects of glucocorticoids (GC) by non-selectively antagonizing the GC receptor. Relacorilant is a selective inhibitor of GC receptor. Finally, some 11 beta-hydroxysteroid dehydrogenase (11BHSD) type 1 (11BHSD1) inhibitors (for example INCB13739, S-707106 and chenodeoxycholic acid) have been suggested to decrease cortisone-to-cortisol conversion, therefore reducing the amount of cortisol (more active) at peripheral target tissues level. Dotted lines are used for not clearly demonstrated pathways. 


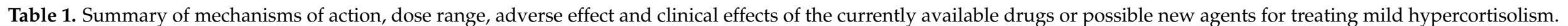

\begin{tabular}{|c|c|c|c|c|c|}
\hline Drug Name & Mechanism of Action & $\begin{array}{l}\text { Usual Dose Range in CS and } \\
\text { Indication }\end{array}$ & $\begin{array}{c}\text { Possible Schedule in } \\
\text { mHC }\end{array}$ & $\begin{array}{c}\text { Main Adverse Events in } \\
\text { CS Patients (\%) }\end{array}$ & $\begin{array}{c}\text { Data on Possible Use in } \\
\text { mHC }\end{array}$ \\
\hline Pasireotide & $\begin{array}{l}\text { SS receptor agonist } \\
\text { - corticotrophs inhibition }\end{array}$ & $\begin{array}{ll}- & 0.3-0.9 \mathrm{mg} \mathrm{SC} \text { bid } \\
- & \mathrm{CD}\end{array}$ & Never tested & $\begin{array}{ll}- & \text { Diarrhea }(45-70) \\
- & \text { Hyperglycemia } \\
& (70-90) \\
-\quad & \text { Nausea }(25-70)\end{array}$ & $\begin{array}{l}\text { No data available in mHC } \\
\text { Hypothetical use in } \\
\text { pituitary } \mathrm{mHC} \text { in the } \\
\text { absence of diabetes }\end{array}$ \\
\hline Pasireotide LAR & $\begin{array}{l}\text { SS receptor agonist } \\
\text { - corticotrophs inhibition }\end{array}$ & $\begin{array}{ll}- & 10-30 \mathrm{mg} \text { IM every } 4 \mathrm{wk} \\
- & \mathrm{CD}\end{array}$ & Never tested & $\begin{array}{ll}- & \text { Diarrhea }(45-70) \\
- & \text { Hyperglycemia } \\
& (70-90) \\
-\quad & \text { Cholelithiasis (20-35) }\end{array}$ & $\begin{array}{l}\text { No data available in mHC } \\
\text { Hypothetical use in } \\
\text { pituitary } \mathrm{mHC} \text { in the } \\
\text { absence of diabetes }\end{array}$ \\
\hline Cabergoline & $\begin{array}{l}\text { DA receptors } \\
\text { - } \quad \text { DR2: corticotrophs inhibition } \\
\text { - } \quad \text { DR1: adrenal cortex cells } \\
\text { stimulation }\end{array}$ & $\begin{array}{ll}- & 0.5-0.7 \mathrm{mg} \text { PO every wk } \\
- & \mathrm{CD}\end{array}$ & Never tested & $\begin{array}{ll}- & \text { Nausea (rare) } \\
\text { - } & \text { Depression (rare) }\end{array}$ & $\begin{array}{c}\text { No data available in mHC } \\
\text { The effect more likely in } \\
\text { patients with less severe } \\
\text { hypercortisolism }\end{array}$ \\
\hline
\end{tabular}

Steroidogenesis inhibitor

- 11-ßhydroxylase inhibition

- 18-hydroxylase inhibition (lesser degree)

Tissue GC metabolism

Metyrapone Pituitary

\section{BHSD inhibition}

- Inhibition of GC-driven positive-feedback (subtypes corticotropinomas)

- $\quad$ SS and DA receptors expression ( $\beta$-arrestin 1 and $\beta$-arrestin 2)

\section{- $\quad$ 250-1500 mg PO qid \\ - $\quad$ CS of any origin}

250-500 mg bid (late afternoon and evening)
Female hirsutism (36)

Dizziness (30)

Arthralgias (15)
Correction of the abnorma circadian rhythm of cortisol if given in the late afternoon and evening Presurgery short-term 
Table 1. Cont.

\begin{tabular}{|c|c|c|c|c|c|}
\hline Drug Name & Mechanism of Action & $\begin{array}{l}\text { Usual Dose Range in CS and } \\
\text { Indication }\end{array}$ & $\begin{array}{l}\text { Possible Schedule in } \\
\text { mHC }\end{array}$ & $\begin{array}{c}\text { Main Adverse Events in } \\
\text { CS Patients (\%) }\end{array}$ & $\begin{array}{c}\text { Data on Possible Use in } \\
\text { mHC }\end{array}$ \\
\hline Ketoconazole & 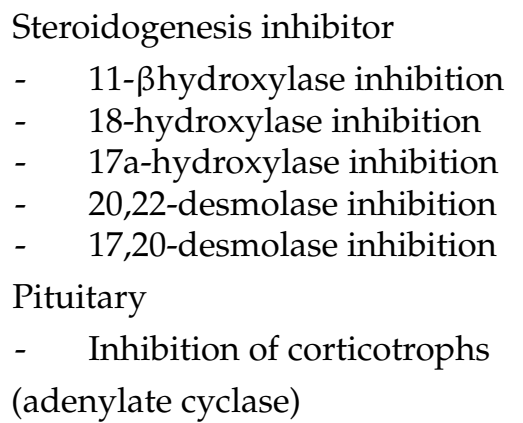 & $\begin{array}{l}\text { - } \quad \text { 200-800 mg PO bid-tid } \\
-\quad \text { CS of any origin }\end{array}$ & 200-400 mg/day & $\begin{array}{ll}- & \text { Epatotoxicity (14.5) } \\
- & \text { Nausea (12.9) } \\
- & \text { AI (11.9) } \\
- & \text { Gynecomastia (17) }\end{array}$ & $\begin{array}{l}\text { Case report showing } \\
\text { cortisol secretion } \\
\text { normalization and blood } \\
\text { pressure amelioration with } \\
\text { low dose } \\
\text { (200-400 mg/day) }\end{array}$ \\
\hline Levoketoconazole & $\begin{array}{l}\text { Steroidogenesis inhibitor } \\
-\quad 11-\beta \text { hydroxylase inhibition } \\
-\quad \text { 18-hydroxylase inhibition } \\
-\quad \text { 17a-hydroxylase inhibition } \\
-\quad \text { 20,22-desmolase inhibition } \\
-\quad 17,20-\text { desmolase inhibition } \\
\text { Pituitary } \\
-\quad \text { Inhibition of corticotrophs } \\
\text { (adenylate cyclase) }\end{array}$ & $\begin{array}{l}-\quad 150-600 \mathrm{mg} \text { PO bid-qid } \\
-\quad \text { CS of any origin }\end{array}$ & Never tested & $\begin{array}{ll}- & \text { Nausea }(30) \\
- & \text { Edema }(19) \\
- & \text { Headache }(28)\end{array}$ & $\begin{array}{l}\text { No data available in mHC } \\
\text { In patients with type } 2 \\
\text { diabetes mellitus without } \\
\text { hypercortisolism } \\
\text { amelioration of } \\
\text { glycometabolic control, } \\
\text { lipid levels, body weight } \\
\text { and blood pressure }\end{array}$ \\
\hline Osilodrostat & $\begin{array}{l}\text { Steroidogenesis inhibitor } \\
\text { - } \quad 11-\beta \text { hydroxylase inhibition }\end{array}$ & $\begin{array}{ll}- & 5-60 \mathrm{mg} \text { PO qd-bid } \\
- & \text { CS of any origin }\end{array}$ & Never tested & $\begin{array}{ll}- & \text { AI symptoms }(32-52) \\
- & \text { Asthenia }(30-58) \\
- & \text { Nausea }(32-42)\end{array}$ & No data available in $\mathrm{mHC}$ \\
\hline Mifepristone & $\begin{array}{c}\text { Non selective GC receptor } \\
\text { antagonist }\end{array}$ & $\begin{array}{ll}- & 300-1200 \mathrm{mg} P O \\
- & \text { CS of any origin }\end{array}$ & $200-400 \mathrm{mg}$ & $\begin{array}{ll}- & \text { Nausea }(48) \\
- & \text { Asthenia }(48) \\
- & \text { Headache }(44)\end{array}$ & $\begin{array}{c}\text { Three studies with } \\
\text { amelioration of insulin } \\
\text { resistance, hypertension, } \\
\text { QoL and cardiometabolic } \\
\text { parameters, with good } \\
\text { tolerability }\end{array}$ \\
\hline
\end{tabular}


Table 1. Cont.

\begin{tabular}{|c|c|c|c|c|c|}
\hline Drug Name & Mechanism of Action & $\begin{array}{l}\text { Usual Dose Range in CS and } \\
\text { Indication }\end{array}$ & $\begin{array}{l}\text { Possible Schedule in } \\
\text { mHC }\end{array}$ & $\begin{array}{c}\text { Main Adverse Events in } \\
\text { CS Patients (\%) }\end{array}$ & $\begin{array}{c}\text { Data on Possible Use in } \\
\text { mHC }\end{array}$ \\
\hline Relacorilant & Selective GC receptor antagonist & $\begin{array}{l}-\quad 100-400 \mathrm{mg} \text { PO qd } \\
-\quad \text { CS of any origin }\end{array}$ & Never tested & $\begin{array}{ll}\text { - } & \text { Back pain (31) } \\
\text { - } & \text { Headache }(26) \\
- & \text { Edema }(26)\end{array}$ & $\begin{array}{l}\text { A phase III, randomized, } \\
\text { double-blind, } \\
\text { placebo-controlled study } \\
\text { (NCT04308590) ongoing }\end{array}$ \\
\hline
\end{tabular}

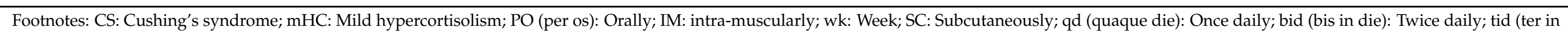

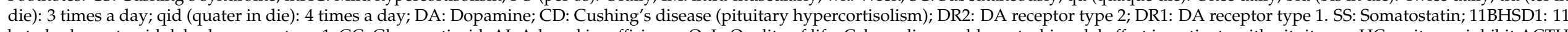

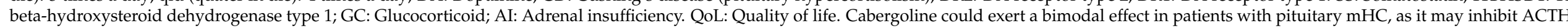

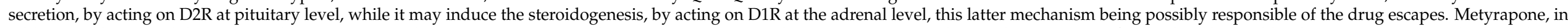

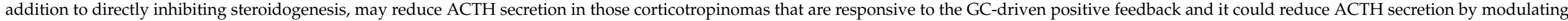
the SS and DA receptors expression thanks to its role on $\beta$-arrestin 1 and $\beta$-arrestin 2. 


\section{Medical Therapy of Mild Hypercortisolism \\ 4.1. Pituitary-Directed Drugs}

To date, very scarce data are available regarding $\mathrm{mHC}$ of pituitary origin. Centrally acting agents act on tumorous corticotroph cells to decrease ACTH secretion [42]. The currently available pituitary-directed drugs include the somatostatin (SST) analogue pasireotide and the dopamine (DA) agonist cabergoline (the latter is currently off-label for patients with Cushing's disease) [43]. The effectiveness of pasireotide and cabergoline is due to the presence of somatostatin receptors (SSTR), including SSTR type 2 and SSTR type 5 , and DA receptors, respectively, in most tumorous corticotroph cells [44].

\subsubsection{Pasireotide}

Being localized in the central nervous system interneurons, including hypothalamic ones, SST acts as a neurotransmitter and controls growth hormone secretion [45]. A possible role of SST in modulating pituitary ACTH secretion has also been demonstrated, with SSTR type 2 and SSTR type 5 being the putative target receptors, expressed on the pituitary corticotroph cells [46]. However, in both healthy subjects and patients with pituitary hypercortisolism, ACTH levels do not decrease following the administration of octreotide, an SST analog with high affinity for SSTR type 2, probably due to the SSTR type 2 downregulation caused by the GC excess exposure itself [46]. At variance with SSTR type 2, SSTR type 5 expression is not influenced by GC exposure as shown in cultures pre-incubated with dexamethasone [47] and in rats [48]. On the basis of these data, SSTR type 5 has been proposed as the real target for SST analogs for the therapy of pituitary hypercortisolism, and a multi-ligand SST analog, pasireotide, with a high affinity for SSTR type 5 (158-fold higher than octreotide) has been developed [49]. Pasireotide is formulated as a subcutaneous injection to be administered twice a day $(0.3-0.9 \mathrm{mg})$. In order to increase compliance, pasireotide LAR has been introduced, which represents a long-acting formulation of pasireotide, requiring a single, intramuscular administration every 4 weeks. Both pasireotide and pasireotide LAR have been shown to be effective in controlling hypercortisolism in pituitary hypercortisolism and are approved by the Food and Drug Administration (FDA) and European Medical Agency (EMA) for patients with pituitary hypercortisolism that are not candidates for surgery or in whom surgery has failed [44].

The main clinical trial on pasireotide treatment is a double-blind, randomized, multicenter clinical trial involving 162 patients. In this study, about $50 \%$ of patients showed substantial amelioration (either $\geq 50 \%$ reduction from baseline or normalization) in UFC levels at six months. A significant amelioration even of the lipid profile and blood pressure and a reduction in body mass index (BMI) and waist circumference were found in the vast majority of patients, partially independently of full disease-activity control. Importantly, the greatest blood pressure decrease was observed in patients who did not receive antihypertensive medications during the study, and normalization of UFC levels was observed more frequently in patients with $\mathrm{mHC}$, defined as a UFC level between 1.5 and 2 times the upper limit of the normal range (ULN) $[43,50]$. A subsequent post-marketing observational study reported an even higher success rate $(67.7 \%)$ in patients with very mild (UFC $<1.5^{*} \mathrm{ULN}$ ) to moderate disease ( $>2 \leq 5^{*} \mathrm{ULN}$ ), confirming that the lower the level of UFC (and therefore the severity of the disease), the higher the rate of UFC normalization [51]. It should be noted that, in this study, three patients with confirmed Cushing's disease but with normal UFC levels at baseline were treated with pasireotide, obtaining marked beneficial effects in the overall clinical picture (mainly a reduction in BMI, waist circumference and blood pressure) [52]. Pasireotide LAR was also shown to be effective in a phase III study on 150 hypercortisolemic patients. Even in this study, approximately $40 \%$ of patients showed normalization of UFC, and higher response rates $(52 \%)$ were documented in patients with lower baseline UFC concentrations $\left(<2^{*}\right.$ ULN). The clinical profile after 12 months of treatment was similar to that of twice-daily subcuta- 
neous pasireotide [52]. Pasireotide and pasireotide LAR adverse effects include abdominal discomfort, bloating, diarrhea, cholelithiasis, and bradycardia, and, of importance, hyperglycemia, which appears as soon as 15 days after the introduction of the drug [53]. This side-effect is independent of the hypercortisolism control and is a consequence of insulin secretion inhibition/suppression of incretin release from the gut [54] and, therefore, careful monitoring of hyperglycemia is mandatory in patients treated with these agents. Given this evidence, the use of pasireotide and pasireotide LAR could be considered in patients with pituitary $\mathrm{mHC}$ in the absence of diabetes.

\subsubsection{Cabergoline}

Cabergoline is a DA agonist, acting on the DA receptors with the highest affinity for DA receptors type 2 (D2R), which are expressed in approximately 60-75\% of corticotroph adenomas [51]. Preclinical data on mice and cellular studies suggested D2R as a potential target for treating patients with pituitary cortisol excess. Indeed, in rodents, the hypothalamic DA neurons, acting through D2R, maintain the intermediate pituitary lobe under tonic inhibition [55]. Similarly, in D2R-deficient mice, a hypertrophic intermediate pituitary lobe and increased ACTH and proopiomelanocortin (the ACTH precursor) expression has been described. In addition, bromocriptine, a DA agonist, has been shown to inhibit the proliferation of murine ACTH-secreting pituitary adenoma cells [56] and cabergoline treatment in primary cultures of canine ACTH-secreting adenomas moderately expressing D2R-reduced ACTH secretion [57]. It is still unclear whether, in humans, the pituitary ACTH characteristics may influence the D2R expression, even though the D2R expression is thought to be present across all corticotroph subtypes [58]. Interestingly, in ACTH-secreting pituitary adenomas causing $\mathrm{mHC}, \mathrm{D} 2 \mathrm{R}$ expression has been found to be lower than in silent ACTH-producing adenomas [59]. Thus, it is not possible to exclude that the tumor features may influence D2R expression levels, potentially affecting DA agonists' effectiveness [60], particularly in mild pituitary hypercortisolism.

Cabergoline is currently suggested as a second-line, off-label treatment for pituitary hypercortisolism [42-44]. A meta-analysis on the use of cabergoline monotherapy in patients with pituitary hypercortisolism showed that the proportion of patients achieving remission was $39.4 \%$. Noteworthily, the meta-analysis showed that responder patients had significantly lower baseline UFC than non-responder patients, suggesting a higher chance of success in patients with $\mathrm{mHC}$ as compared to patients with severe disease. However, during a long-term follow-up, 8 out of 36 patients $(22.2 \%)$ who responded to cabergoline monotherapy experienced treatment escape [61]. The reasons for this escape are still poorly understood. Interestingly, in a study on human-induced pluripotent stem cells, cabergoline was described as an inducer of $3 \beta$-hydroxysteroid dehydrogenase, an essential enzyme for adrenogonadal steroidogenesis. Although cabergoline is a potent D2R agonist, it may act, though with lower affinity, even on DA receptor type 1 (D1R), which has been shown to upregulate the expression of various steroidogenic enzymes and increase the secretion of steroid hormones synergistically with ACTH [62]. Thus, cabergoline could exert a bimodal effect in patients with pituitary $\mathrm{mHC}$, as it may inhibit ACTH secretion by acting on D2R at the pituitary level, and induce steroidogenesis by acting on D1R at the adrenal level. Moreover, from a clinical perspective, cabergoline treatment seems to also have beneficial effects in cortisol-related comorbidities, mainly arterial hypertension and glycemic control and body weight [63].

Cabergoline therapy is usually well-tolerated, even though some patients actually report nausea, vomiting and orthostatic dizziness. In a lower percentage of patients, headache, nasal congestion, constipation, digital vasospasm, nightmares, anxiety and depression may occur [43]. In general, cabergoline may represent an effective treatment in patients with pituitary $\mathrm{mHC}$ when considering its low cost, the oral route of administration and good tolerance. 


\subsection{Adrenal Steroidogenesis Inhibiting Agents}

\subsubsection{Metyrapone}

Metyrapone is a steroidogenesis inhibitor acting mainly against the adrenal $11 \beta-$ hydroxylase, a crucial enzyme responsible for the conversion of 11-deoxycortisol in cortisol and of 11-deoxycorticosterone in corticosterone, an aldosterone precursor. Metyrapone therefore induces a decrease in GC and mineralocorticoid production and secretion. Moreover, it is also an inhibitor, to a lesser degree, of 18-hydroxylase [64]. Metyrapone was also demonstrated to have an extra-adrenal effect, as it influences the peripheral GC metabolism through the regulation of 11BHSD1 activity [65]. The metyrapone immediaterelease capsule, which contains a $250 \mathrm{mg}$ dose with a maximum daily dose of $6 \mathrm{~g} /$ day, is suggested $[42,66]$. Metyrapone is administered orally and absorbed quickly. With a short half-life $(2 \mathrm{~h})$ and a peak plasma concentration within $1 \mathrm{~h}$ from ingestion, this agent represents a highly manageable treatment option in patients with hypercortisolism. Metyrapone, according to a recent meta-analysis, has an estimated average CS remission rate of 75.9\% [67]. Metyrapone treatment substantially reduces serum cortisol and aldosterone, while it increases the androgenic and mineralocorticoid precursors (predominantly 11-deoxycorticosterone, 11-deoxycortisol) levels. About $50-70 \%$ of CS patients treated with metyrapone experience the normalization of cortisol parameters. It is essential that any cortisol assay used for monitoring patients treated with metyrapone does not cross react with 11-deoxyxcortisol to avoid an erroneous increase in drug dose due to an apparent increase in plasma cortisol levels [68].

Metyrapone has been reported to improve hypertension, glucose metabolism and psychiatric disturbances in CS patients. In a single-center retrospective study on 91 patients, psychiatric disturbances, glucose intolerance or diabetes mellitus and hypertension improved in $73 \%, 82 \%$ and $70 \%$ of patients, respectively [69]. As reported by an observational study on 31 patients, the effect of metyrapone on blood pressure is variable, with the new onset of hypertension or its worsening being described in about $28.6 \%$ and $20.8 \%$ of cases, respectively, while blood pressure amelioration or normalization occurred in $16.6 \%$ of patients [70]. To date, there is still little evidence for the use of metyrapone in patients with $\mathrm{mHC}$. In a recent proof-of-concept study, metyrapone was administered in six patients with autonomous cortisol secretion and adrenal incidentaloma. In these patients with proved increased evening and nocturnal cortisol levels, metyrapone was administered with the aim of restoring the normal cortisol circadian rhythm. In detail, a first metyrapone dose (500 mg) was administered at 6 PM and a second dose $(250 \mathrm{mg}$ ) was administered at 10 $\mathrm{pm}$. This administration schedule led to a correction of the abnormal circadian rhythm of cortisol secretion, thus suggesting the possible use of low doses of metyrapone in patients with $\mathrm{mHC}$ with the aim to restore the physiological rhythm of cortisol [71].

The increased levels of androgenic precursors may lead to hirsutism and acne, while increasing levels of the mineralocorticoid precursor can lead to edema, hypokalemia and hypertension at high doses of the drug [64]. Moreover, the loss of negative feedback due to low circulating cortisol levels may then lead to an increase in ACTH levels, which drives the accumulation of cortisol and aldosterone precursors and androgens in blood and urine [70]. The most frequent side effects of metyrapone are gastrointestinal disturbances such as nausea and abdominal discomfort, with other side effects such as hirsutism in females, dizziness and arthralgias being less common [64]. The rationale of using metyrapone in subjects affected by ACTH-independent hypercortisolism is that, in these patients, the compensatory rise of ACTH secretion during treatment should not be observed, since $\mathrm{ACTH}$ is chronically suppressed by the autonomous cortisol secretion. As a consequence, in these patients, the side effects caused by an ACTH-mediated increase in steroid precursors with weak mineralocorticoid activity (increased blood pressure, edema and hypokalemia) or androgen effects (hirsutism, acne, irregular menstrual cycles) should not occur. This has been confirmed in the only available prospective study on seven patients, in whom a short-term (i.e., 3 months) metyrapone course at a mean dose of $750 \mathrm{mg} /$ day was given as preoperative therapy in patients with adrenal hypercortisolism [72]. Indeed, in this study, 
all patients showed normalization of UFC levels from baseline to the end of the follow-up with a reduction of serum and salivary cortisol levels, and no significant increase in plasma ACTH and serum dehydroepiandrosterone sulfate levels [72]. The quality of life and blood pressure control were ameliorated in all patients, while no significant change in weight, electrolytes, or glycemic and lipid profile was reported. In spite of a significant increase in testosterone and androstenedione levels in women, clinical hyperandrogenism did not worsen and, in general, all drug-related adverse events were grade 1 or 2 and generally transient. Of note, three out of seven patients were affected by mHC (i.e., UFC levels less than 1.5-fold higher than the upper limit of the normal range) [72].

Finally, very recently, a Japanese research group described the case of a patient affected by pituitary hypercortisolism, who showed GC-driven positive feedback and both ACTH suppression and tumor shrinkage by metyrapone [73]. The same authors revealed that in a cohort study, $8.7 \%$ of patients with pituitary hypercortisolism may display a GC-driven positive-feedback, representing a possible new subtype of pituitary hypercortisolism. The molecular mechanisms underlying these effects of metyrapone are still unknown, but it may be due to a GC-mediated effect on the corticotrophs. Indeed, it has been shown that the GC dexamethasone is able to suppress tumor growth by inhibiting tumor angiogenesis by reducing interleukin- 8 and endothelial growth factors and by upregulating microRNA-708 expression. Other data pointed out that dexamethasone may potentially enhance tumor growth by inhibiting p53-mediated apoptosis and stimulating protein kinase $\mathrm{B}$ and the mitogen-activated protein kinase [74]. Moreover, recent data on murine corticotroph AtT20 cells showed that dexamethasone causes an increase and a decrease in the expression of $\beta$-arrestin 1 and $\beta$-arrestin 2 , respectively, which are proteins involved in the regulation of SST and DA receptors [75]. However, consistent with a direct effect of metyrapone on ACTH-secreting cells is the finding of spontaneous ACTH normalization and tumor regression induced by metyrapone in a patient with ectopic ACTH syndrome [76].

Overall, these preliminary data suggest that metyrapone could represent an option for medical therapy even in mHC. In Europe, metyrapone has been approved for the management of CS by EMA in April 2014, while it is still an off-label treatment in the United States.

\subsubsection{Ketoconazole}

Ketoconazole (KTZ) is an imidazole derivative, originally conceived as an orally active antifungal agent. In fungi, KTZ inhibits the synthesis of ergosterol, a cell membrane sterol, through the enzymatic blockade of several fungal steroidogenesis enzymes [77]. However, later in vitro and in vivo studies showed that KTZ was able to inhibit adrenal steroidogenesis [78]. Ketoconazole has a relatively short half-life ( $3.3 \mathrm{~h})$, therefore requiring a twiceor thrice-daily administration schedule. It is formulated as an immediate-release tablet, containing a $200 \mathrm{mg}$ dose, with a maximum total daily dose of $1200 \mathrm{mg} /$ day [42]. It is currently available as a 50/50 racemic mixture of two enantiomers, levoketoconazole ( $2 \mathrm{~S}, 4 \mathrm{R}$ stereoisomer) and dextroketoconazole ( $2 \mathrm{R}, 4 \mathrm{~S}$ stereoisomer), with these enantiomers exhibiting differences in inhibitory potency for the enzymes involved in steroidogenesis [79]. In the adrenal cortex, KTZ blocks multiple steps of steroid biosynthesis through the inhibition of cytochrome p450 enzymes 17a-hydroxylase, 20,22-desmolase, 11b-hydroxylase, 17,20desmolase and 18-hydroxylase, therefore inducing a decrease in GC, mineralocorticoid and adrenal androgen production and secretion [64]. Ketoconazole has also been reported to directly inhibit ACTH secretion, thus potentially suggesting a double pharmacodynamic action of potential use in patients with pituitary hypercortisolism, although these mechanisms are still debated [79]. Finally, as for metyrapone, a possible inhibitory effect of KTZ on corticotrophs has been hypothesized. Indeed, in vitro data found that KTZ inhibited ACTH secretion at therapeutic doses by impairing adenylate cyclase activation in corticotrophs [80].

Noteworthily, KTZ impairs not only adrenal but also gonadal steroidogenesis, in particular with a negative effect on testicular androgen production, thus potentially leading 
to male hypogonadism [42]. Importantly, ketoconazole is a potent inhibitor of CYP3A4 and thus may increase the availability of drugs metabolized through this enzyme [43]. Ketoconazole is also listed among drugs that prolong the QT interval and may increase the risk of torsade de pointes. This possible adverse event, however, was not confirmed in a study that found that long-term ketoconazole administration does not appear to be associated with a significant prolongation of the QT interval in patients with CD [77]. Moreover, KTZ inhibits liver enzymes involved in the metabolism of chemical substances not normally found or expected to be present in the human organism, therefore favoring the occurrence of liver damage [42]. In a metanalysis, Yan and coauthors showed that the incidence of KTZ-associated hepatotoxicity was 3.6-4.2\%, independently of the dosage and treatment duration [81]. In the majority of cases, KTZ caused an asymptomatic increase in liver transaminases. However, fatal hepatitis has been reported in patients receiving $200 \mathrm{mg}$ daily after both short- and long-term treatment courses [64]. This is why the FDA has mandated the insertion of a "black box" warning on the ketoconazole label to inform patients and physicians of the risk of serious hepatotoxicity associated with medication use and recommend regular monitoring of liver chemistries [82]. Overall, the main adverse events (12-15\% frequency) associated with KTZ use are liver enzymes elevation, gastrointestinal disturbances, gynecomastia and adrenal insufficiency [42].

One recent metanalysis reported an estimated average remission rate of hypercortisolism with the use of KTZ of about 71\% [67]. Although it has been used for decades, no prospective studies are available regarding the effect of KTZ for treating the hypercortisolemic states [25]. A French study retrospectively assessing data from 38 patients with CS receiving ketoconazole for a median of 23 months showed, 3-6 months after the initiation of KTZ, blood pressure normalization in all patients, an improvement in metabolic control in all diabetic patients, a marked regression of cardiac signs in a patient who had severe heart failure and a dramatic increase in bone mineral density in three patients followed up for at least 36 months [83]. The largest retrospective study on the use of KTZ in CS, including 200 patients from 14 centers in France treated for more than 24 months, showed the improvement of hypertension, diabetes and hypokalemia in $55.5 \%, 50 \%$ and $87.5 \%$ of patients, respectively [84].

The possible use of KTZ in patients with $\mathrm{mHC}$ has been scarcely investigated. ComtePerret et al. reported a case of a 48-year-old woman with bilateral macronodular adrenal hyperplasia (BMAH) with biochemical hypercortisolism without specific signs of CS, treated for 10 years with low doses (200 to $400 \mathrm{mg}$ /day) of ketoconazole to control cortisol secretion. At diagnosis, the patient presented with marked hypertension, which rapidly normalized and required only small doses of spironolactone and metoprolol after the beginning of KTZ. Ketoconazole therapy caused rapid normalization of cortisol and ACTH that persisted over 10 years on treatment, with no adrenal changes in size [85]. To date, we still do not know if KTZ may also be used in $\mathrm{mHC}$, since the side effects may outweigh the benefits. In November 2014, KTZ was approved for CS treatment by EMA, whereas it is still an off-label treatment in the United States [42].

\subsubsection{Levoketoconazole}

Levoketoconazole (levoKTZ), an orally administered KTZ stereoisomer, is currently under clinical trials for the treatment of CS. LevoKTZ, formulated as a $150 \mathrm{mg}$ immediaterelease tablet, is the purified $2 \mathrm{~S}, 4 \mathrm{R}$ enantiomer of KTZ. Based on early in vitro analyses, levoKTZ inhibits cytochrome P450 family 11 subfamily B member 1 (CYP11ß1, coding for $11 \beta$-hydroxylase enzyme), cytochrome P450 Family 17 Subfamily A Member 1 (CYP17 $\alpha 1$, coding for $17 \alpha$-hydroxylase enzyme) and cytochrome P450 family 21 subfamily A member 2 (CYP21 $\alpha 2$, coding $21 \alpha$-hydroxylase enzyme), 15- to 25 -fold more potently compared to the $2 \mathrm{R}, 4 \mathrm{~S} \mathrm{KTZ}$ enantiomer. This may allow for a lower dose of levoKTZ compared to racemic KTZ to achieve the same efficacy and, consequently, less hepatotoxic effects. Together with a favorable safety profile and an increased therapeutic index, levoKTZ is a promising novel treatment option for CS [82]. Similar to ketoconazole, levoKTZ is a 
substrate and a potent inhibitor of a major drug-metabolizing enzyme, CYP3A4, potentially leading to relevant drug-drug interactions [86].

LevoKTZ was initially investigated as a potential treatment for type 2 diabetes mellitus [87]. In a small, randomized, double-blind, placebo-controlled study in patients with type 2 diabetes mellitus without hypercortisolism, levoKTZ ameliorated lipid levels and reduced body weight and blood pressure [88]. However, levoKTZ therapy was associated with gastrointestinal side effects and the development of this drug for type 2 diabetes was interrupted due to safety concerns $[64,88,89]$. The mechanisms explaining the beneficial effects of levoKTZ on diabetes, lipid profile and hypertension, regardless of the presence of hypercortisolism, are still largely unknown. However, it is known that diabetic patients may have increased hypothalamic-pituitary-adrenal axis activity, in particular in the presence of diabetic complications $[90,91]$. In addition, recent data show that the presence of hypertension and/or diabetes and/or fragility fractures is associated with cortisol secretion, peripheral activation (as reflected by the 11BHSD1 activity) and GC sensitivity (as mirrored by the GR gene sensitizing variants). Therefore, it is not possible to exclude that modulating cortisol secretion may be beneficial for lipid levels, glycometabolic and blood pressure control even in patients without documented cortisol hypersecretion [92,93].

On the basis of these promising results on glucose metabolism, levoKTZ was studied in 94 patients affected by CS in a phase III, open-label, multicenter clinical trial (SONICS study), which found UFC normalization in $46 \%$ and $33 \%$ of patients with diabetes mellitus and without diabetes mellitus, respectively. Interestingly, in diabetic patients, who were adequately controlled at baseline, levoKTZ treatment led to a clear amelioration of glycometabolic control (i.e., glycated hemoglobin decreased from $6.9 \%$ to $6.2 \%$ ), and a decrease in glycated hemoglobin (i.e., from $5.5 \%$ to $5.3 \%$ ) was noted even in nondiabetic patients [94]. In addition, after the 6-month maintenance period, a significant decrease in body weight, peripheral edema and acne and hirsutism in women as well as an improvement in quality of life and depressive status was observed [94,95]. These data now need to be confirmed in the phase III, double-blind, multicenter clinical trial (LOGICS study) that was started in September 2017 to assess the efficacy and safety of levoKTZ treatment in CS patients, of which no preliminary data have been available so far (https:/ / clinicaltrials.gov / ct2/show /NCT03277690; accessed date: 21 October 2021).

Similar to what was already shown for KTZ, levoKTZ also seems to inhibit cell growth and ACTH secretion in mouse pituitary tumor cells (AtT20) and in primary human pituitary adenoma culture [96].

Given the beneficial effects of levoKTZ on diabetes mellitus and hypertension, even in patients without documented hypercortisolism, and the possibility to use lower doses as compared with KTZ, levoKTZ seems to be a possible effective treatment for $\mathrm{mHC}$, in particular in patients with HidHyCo found during the screening for possible secondary forms of diabetes mellitus and hypertension.

\subsubsection{Osilodrostat}

Osilodrostat (LCI699) is a novel oral steroidogenesis inhibitor, licensed by EMA in January 2020 for the treatment of endogenous CS in adults and by the FDA in March 2020 for the treatment of patients with pituitary hypercortisolism, who either cannot undergo pituitary surgery or have persistent disease after pituitary surgery [42]. Osilodrostat is a steroidogenesis inhibitor that inhibits the enzyme CYP11 $\beta 1$, which is responsible for the conversion of 11-deoxycortisol to cortisol and of 11-deoxycorticosterone to corticosterone. The drug also inhibits aldosterone synthase (CYP11ß2), the enzyme involved in the conversion of 11-deoxycorticosterone to aldosterone [97]. Therefore, similarly to metyrapone, it induces a decrease in GC and mineralocorticoid production and secretion [97]. Osilodrostat only modestly suppresses androstenedione, dehydroepiandrosterone-sulphate, testosterone and 17-hydroxyprogesterone production, whereas it increases progesterone production [68]. Osilodrostat is formulated as immediate-release tablets, with a maximum dose of $60 \mathrm{mg} /$ day and a 4-h half-life, allowing a twice-daily administration [98]. Os- 
ilodrostat clinical efficacy and tolerability have been proven in phase 2 and 3 trials with CD patients who have had an inadequate response to transsphenoidal surgery (TSS) after conventional first-line treatment [98]. A complete biochemical response, occurring as early as 12 weeks, has been documented in $66 \%$ of patients at 48 weeks with clinical improvements being observed in most cardiovascular-related metabolic parameters including body weight, BMI, fasting plasma glucose, blood pressure and lipid profile [99].

Osilodrostat is generally well tolerated with relatively rare side effects, including nausea, diarrhea, fatigue, headache, oedema and hypokalemia, together with hirsutism and acne in women $[98,99]$.

In patients with $\mathrm{mHC}$, due to the reported possible occurrence of cortisol withdrawal syndrome related to the great potency of osilodrostat, early and frequent clinical monitoring is needed, particularly in the first weeks of treatment. The risk of delayed acute adrenal insufficiency in patients treated with a stable dose of osilodrostat has also been recently documented [100].

\subsection{Glucocorticoid Receptor-Directed Drugs}

\subsubsection{Mifepristone}

Mifepristone is an oral non-selective GR antagonist, officially approved by EMA in February 2012 for the treatment of CS of any cause, if the patient has glucose intolerance and hypertension, or both, and cannot undergo or refuses surgery [42,68]. In Europe, no official approval has been granted to mifepristone as a treatment for CS [68]. Mifepristone has a rapid onset of action and it is prescribed with a maximum daily dose of $1200 \mathrm{mg}$. Its long half-life (24-90 h) allows a once-daily administration [68]. Mifepristone was discovered in the early 1980s and due to its anti-progestin activity, it has been used as a contraceptive [101].

Thereafter, mifepristone at higher doses was demonstrated to have an inhibitory effect on GR [102]. Indeed, mifepristone directly acts on GR and, thus, it does not reduce cortisol secretion but rather inhibits its peripheral effects [68]. As a consequence, by blocking the GR, mifepristone raises the secretion of ACTH and, consequently, cortisol levels are increased. If this increase in cortisol levels exceeds the capacity of the renal 11BHSD type 2 (11BHSD2) enzyme to inactivate cortisol, a state of apparent mineralocorticoid excess, including hypokalemia, arterial hypertension and peripheral edema, may occur [46]. Moreover, being a non-selective steroid receptor antagonist, mifepristone also binds androgen and progestin receptors, inhibiting their peripheral effects. In particular, the anti-progestin effect is characterized by endometrial thickening and abnormal vaginal bleeding [103], which, however, occurs rarely. The most common adverse effects of mifepristone include nausea and fatigue, possible manifestations of adrenal insufficiency. As the mifepristone mechanism of GR antagonism does not allow one to rely on the commonly used biochemical parameters of hypercortisolism due to the compensatory rise in circulating cortisol levels, the evaluation of efficacy is exclusively based on clinical symptoms [43].

A study evaluating the clinical effects of mifepristone monotherapy in 50 patients with CS found an improvement in hypertension and glucose tolerance in 38\% and $60 \%$ of patients, respectively. Overall, an improvement in clinical status was observed in $87 \%$ of patients, mirrored by the amelioration of depression, cognitive function and quality of life [104]. Mifepristone ameliorated weight, and this beneficial effect on weight loss persisted for an additional two years in patients who remained on therapy [105]. Mifepristone was also studied in patients with $\mathrm{mHC}$ and bilateral macronodular adrenal hyperplasia (BMAH). In their first study in 2013, Debono and colleagues treated six individuals with adrenal incidentalomas and $\mathrm{mHC}$ with mifepristone $200 \mathrm{mg}$ twice daily for 4 weeks. Across the group, there was a significant reduction in insulin resistance as five out of six individuals showed a reduction in insulin, and in two patients, a clinically significant cardiovascular benefit was shown [106]. These results were confirmed by the second study performed in eight patients with $\mathrm{mHC}$ and unilateral or bilateral adrenal incidentalomas. Mifepristone, administered $300 \mathrm{mg}$ daily over 6 months, led to a significant reduction in insulin resistance 
as measured and an improvement in Beck's Depression Inventory scores and Cushing's Quality of Life scores in most patients [107]. In the same year, other authors showed that mifepristone was able to induce an improvement in cardiometabolic parameters as early as 2 weeks after treatment initiation in 4 patients with BMAH, who also experienced an amelioration of glycemic control and hypertension as well as weight loss [108]. Overall, the possible use of mifepristone as a treatment of adrenal $\mathrm{mHC}$ for patients with impaired glucose metabolism is hindered by its adverse events (abnormal vaginal bleeding, edema and potential hypocortisolism).

\subsubsection{Relacorilant}

Relacorilant is a novel oral GR antagonist, currently under clinical evaluation for CS and $\mathrm{mHC}$ treatment [42]. This drug has been developed to overcome the mifepristone limits, related to the low selectivity in antagonizing the GR.

A single-arm, open-label, phase 2, dose-finding study with two dose groups was conducted between June 2016 and September 2018 at 19 sites in the USA and Europe. Low-dose relacorilant (100-200 mg/d) or high-dose relacorilant was administered for 12 weeks in 17 CS patients or for 16 weeks in 18 CS patients, respectively. Doses were up-titrated by $50 \mathrm{mg}$ every 4 weeks. Hypertension was ameliorated in $41.7 \%$ and $63.6 \%$ of patients and glucose metabolism improved in $15.4 \%$ and $50.0 \%$ of patients in the low-dose group and high dose group, respectively. The most common adverse events included back pain, headache, peripheral edema, nausea, pain at extremities, diarrhea and dizziness, with no patients reporting vaginal bleeding or hypokalemia [109]. Currently, a phase III, randomized, double-blind, placebo-controlled, clinical trial (GRACE, NCT 03697109) is ongoing with the aim of assessing the efficacy and safety of relacorilant treatment in CS patients.

Given its more selective effect on GR and the better safety profile as compared with mifepristone and the promising results with this latter drug in patients with $\mathrm{mHC}$, relacorilant represents an interesting possibility for patients affected with $\mathrm{mHC}$ and hypertension or glucose metabolism impairment. Currently, a phase III, randomized, double-blind, placebo-controlled study (GRADIENT, NCT04308590) is ongoing with the aim of assessing the efficacy and safety of relacorilant to treat hypercortisolism in patients with cortisolsecreting adrenal adenoma or hyperplasia associated with diabetes mellitus/impaired glucose tolerance and/or uncontrolled systolic hypertension.

\section{Conclusions}

Mild hypercortisolism is a relatively common condition that may lead to negative metabolic, cardiovascular and psychological outcomes. To date, no guidelines are available regarding its management. From a pharmacological perspective, only metyrapone and mifepristone have been recently studied in this setting specifically, with interesting results, that do, however, need to be confirmed in larger studies. Pasireotide and cabergoline also seem to have potential use in pituitary $\mathrm{mHC}$, taking care to avoid pasireotide in patients with glucose impairment. Even the use of ketoconazole can be considered in mHC patients, carefully evaluating the risk of potential adverse effects as well as potential drug-drug interactions. Nowadays, these drugs could be considered in the cure of $\mathrm{mHC}$ in patients in whom surgery is refused or contra-indicated and in whom hypertension and diabetes control is of concern. Besides levoKTZ and osilodrostat, which could be of interest in future studies, and relacorilant, which is now on trial, in the future, other molecular targets could be considered. Indeed, the 11BHSD1 enzyme is among the determinants of the GC exposure at the peripheral target tissues and its modulation has been already advocated as a possible drug target for treating hypercortisolemic states, both functional and tumor induced [35]. Indeed, selective inhibitors of the hepatic 11BHSD1 have been suggested to be potentially useful for patients with $\mathrm{mHC}$ and insulin resistance and/or diabetes [41,110], but also in eucortisolemic patients with diabetes [111]. 
Given the not-negligible prevalence of $\mathrm{mHC}$ and the importance of its consequences, further studies on potential therapeutic targets for mHC are warranted.

Author Contributions: Conceptualization, I.C., C.A., V.M., A.F., A.G., F.V., L.G. and A.S.; methodology, I.C., C.A. and V.M.; software, I.C., V.F. and A.C.; validation, C.A., V.M., A.C., V.F., L.G. and A.S.; formal analysis: A.G., C.A., A.F. and F.V.; investigation, I.C., C.A., V.M., A.F., A.G., F.V., L.G., A.S., V.F. and A.C.; resources, I.C., A.S. and C.A.; data curation, C.A., V.F. and A.C.; writing-original draft preparation, C.A., A.C., V.F. and I.C.; writing-review and editing, C.A., V.F., A.C., L.G., A.S., A.F. and F.V.; visualization, L.G., A.S., A.F. and F.V.; supervision, I.C., C.A., L.G., F.V., A.S. and A.F.; project administration, I.C.; funding acquisition, I.C. and C.A. All authors have read and agreed to the published version of the manuscript.

Funding: This work has been partially supported by the Istituto Auxologico Italiano, Grant Precor Study, 29_01_06.

Institutional Review Board Statement: Not applicable.

Informed Consent Statement: Not applicable.

Data Availability Statement: Not applicable.

Conflicts of Interest: All authors declare no support from any organization for the submitted work. V.F., A.C., A.F., L.G., A.S. and A.G. have no financial relationships with any organizations that might have an interest in the submitted work in the previous three years and no other relationships or activities that could appear to have influenced the submitted work. I.C., C.A. and V.M. are investigators in studies on relacorilant (Corcept Therapeutics) in patients with hypercortisolism. I.C. received consulting fees from Corcept Therapeutics and HRA Pharma.

\section{References}

1. Nieman, L.K. Cushing's syndrome: Update on signs, symptoms and biochemical screening. Eur. J. Endocrinol. 2015, 173, M33-M38. [CrossRef] [PubMed]

2. Chiodini, I. Diagnosis and Treatment of Subclinical Hypercortisolism. J. Clin. Endocrinol. Metab. 2011, 96, 1223-1236. [CrossRef]

3. Morelli, V.; Ghielmetti, A.; Caldiroli, A.; Grassi, S.; Siri, F.M.; Caletti, E.; Mucci, F.; Aresta, C.; Passeri, E.; Pugliese, F.; et al. Mental Health in Patients with Adrenal Incidentalomas: Is There a Relation with Different Degrees of Cortisol Secretion? J. Clin. Endocrinol. Metab. 2021, 106, e130-e139. [CrossRef]

4. Aresta, C.; Favero, V.; Morelli, V.; Giovanelli, L.; Parazzoli, C.; Falchetti, A.; Pugliese, F.; Gennari, L.; Vescini, F.; Salcuni, A.; et al. Cardiovascular complications of mild autonomous cortisol secretion. Best Pract. Res. Clin. Endocrinol. Metab. 2021, $35,101494$. [CrossRef]

5. Zavatta, G.; Di Dalmazi, G. Recent Advances on Subclinical Hypercortisolism. Endocrinol. Metab. Clin. N. Am. 2018, 47, 375-383. [CrossRef] [PubMed]

6. Di Dalmazi, G.; Vicennati, V.; Garelli, S.; Casadio, E.; Rinaldi, E.; Giampalma, E.; Mosconi, C.; Golfieri, R.; Paccapelo, A.; Pagotto, U.; et al. Cardiovascular events and mortality in patients with adrenal incidentalomas that are either non-secreting or associated with intermediate phenotype or subclinical Cushing's syndrome: A 15-year retrospective study. Lancet Diabetes Endocrinol. 2014, 2, 396-405. [CrossRef]

7. Chiodini, I.; Eller-Vainicher, C.; Morelli, V.; Palmieri, S.; Cairoli, E.; Salcuni, A.S.; Copetti, M.; Scillitani, A. Mechanisms in endocrinology: Endogenous subclinical hypercortisolism and bone: A clinical review. Eur. J. Endocrinol. 2016, 175, R265-R282. [CrossRef]

8. Debono, M.; Bradburn, M.; Bull, M.; Harrison, B.; Ross, R.J.; Newell-Price, J. Cortisol as a Marker for Increased Mortality in Patients with Incidental Adrenocortical Adenomas. J. Clin. Endocrinol. Metab. 2014, 99, 4462-4470. [CrossRef] [PubMed]

9. Kjellbom, A.; Lindgren, O.; Puvaneswaralingam, S.; Löndahl, M.; Olsen, H. Association between Mortality and Levels of Autonomous Cortisol Secretion by Adrenal Incidentalomas. Ann. Intern. Med. 2021, 174, 1041-1049. [CrossRef]

10. Patrova, J.; Kjellman, M.; Wahrenberg, H.; Falhammar, H. Increased mortality in patients with adrenal incidentalomas and autonomous cortisol secretion: A 13-year retrospective study from one center. Endocrine 2017, 58, 267-275. [CrossRef] [PubMed]

11. Elhassan, Y.; Alahdab, F.; Prete, A.; Delivanis, D.A.; Khanna, A.; Prokop, L.; Murad, M.H.; O’Reilly, M.W.; Arlt, W.; Bancos, I. Natural History of Adrenal Incidentalomas with and without Mild Autonomous Cortisol Excess. Ann. Intern. Med. 2019, 171, 107-116. [CrossRef] [PubMed]

12. Li, D.; Kaur, R.J.; Zhang, C.D.; Ebbehoj, A.; Singh, S.; Atkinson, E.J.; Achenbach, S.J.; Rocca, W.; Khosla, S.; Bancos, I. Risk of bone fractures after the diagnosis of adrenal adenomas: A population-based cohort study. Eur. J. Endocrinol. 2021, 184, 597-606. [CrossRef] [PubMed] 
13. Giovanelli, L.; Aresta, C.; Favero, V.; Bonomi, M.; Cangiano, B.; Eller-Vainicher, C.; Grassi, G.; Morelli, V.; Pugliese, F.; Falchetti, A.; et al. Hidden hypercortisolism: A too frequently neglected clinical condition. J. Endocrinol. Investig. 2021, 44, 1581-1596. [CrossRef]

14. Fassnacht, M.; Arlt, W.; Bancos, I.; Dralle, H.; Newell-Price, J.; Sahdev, A.; Tabarin, A.; Terzolo, M.; Tsagarakis, S.; Dekkers, O. Management of adrenal incidentalomas: European Society of Endocrinology Clinical Practice Guideline in collaboration with the European Network for the Study of Adrenal Tumors. Eur. J. Endocrinol. 2016, 175, G1-G34. [CrossRef]

15. Terzolo, M.; Stigliano, A.; Chiodini, I.; Loli, P.; Furlani, L.; Arnaldi, G.; Reimondo, G.M.; Pia, A.; Toscano, V.; Zini, M.; et al. AME Position Statement on adrenal incidentaloma. Eur. J. Endocrinol. 2011, 164, 851-870. [CrossRef] [PubMed]

16. Pasternak, J.D.; Seib, C.D.; Seiser, N.; Tyrell, J.B.; Liu, C.; Cisco, R.M.; Gosnell, J.E.; Shen, W.T.; Suh, I.; Duh, Q.-Y. Differences Between Bilateral Adrenal Incidentalomas and Unilateral Lesions. JAMA Surg. 2015, 150, 974-978. [CrossRef] [PubMed]

17. Morelli, V.; Palmieri, S.; Salcuni, A.S.; Eller-Vainicher, C.; Cairoli, E.; Zhukouskaya, V.; Scillitani, A.; Beck-Peccoz, P.; Chiodini, I. Bilateral and unilateral adrenal incidentalomas: Biochemical and clinical characteristics. Eur. J. Endocrinol. 2013, 168, $235-241$. [CrossRef] [PubMed]

18. Chiodini, I.; Ramos-Rivera, A.; Marcus, A.O.; Yau, H. Adrenal Hypercortisolism: A Closer Look at Screening, Diagnosis, and Important Considerations of Different Testing Modalities. J. Endocr. Soc. 2019, 3, 1097-1109. [CrossRef]

19. Nieman, L.K.; Biller, B.M.K.; Findling, J.W.; Newell-Price, J.; Savage, M.O.; Stewart, P.M.; Montori, V. The Diagnosis of Cushing's Syndrome: An Endocrine Society Clinical Practice Guideline. J. Clin. Endocrinol. Metab. 2008, 93, 1526-1540. [CrossRef] [PubMed]

20. Toini, A.; Dolci, A.; Ferrante, E.; Verrua, E.; Malchiodi, E.; Sala, E.; Lania, A.G.; Chiodini, I.; Beck-Peccoz, P.; Arosio, M.; et al. Screening for ACTH-dependent hypercortisolism in patients affected with pituitary incidentaloma. Eur. J. Endocrinol. 2015, 172, 363-369. [CrossRef] [PubMed]

21. Aresta, C.; Soranna, D.; Giovanelli, L.; Favero, V.; Parazzoli, C.; Gennari, L.; Persani, L.; Scillitani, A.; Blevins, L.S.; Brown, D.; et al. Endocrine Practice When to suspect hidden hypercortisolism in type 2 diabetes: A meta-analysis. Endocr. Pract. 2021. [CrossRef] [PubMed]

22. Bancos, I.; Alahdab, F.; Crowley, R.K.; Chortis, V.; Delivanis, D.A.; Erickson, D.; Natt, N.; Terzolo, M.; Arlt, W.; Young, W.F.; et al. Improvement of cardiovascular risk factors after adrenalectomy in patients with adrenal tumors and subclinical Cushing's syndrome: A systematic review and meta-Analysis. Eur. J. Endocrinol. 2016, 175, R283-R295. [CrossRef] [PubMed]

23. Salcuni, A.S.; Morelli, V.; Vainicher, C.E.; Palmieri, S.; Cairoli, E.; Spada, A.; Scillitani, A.; Chiodini, I. Adrenalectomy reduces the risk of vertebral fractures in patients with monolateral adrenal incidentalomas and subclinical hypercortisolism. Eur. J. Endocrinol. 2016, 174, 261-269. [CrossRef]

24. Vassiliadi, D.A.; Partsalaki, E.; Tsagarakis, S. Approach to patients with bilateral adrenal incidentalomas. Curr. Opin. Endocrinol. Diabetes Obes. 2020, 27, 125-131. [CrossRef] [PubMed]

25. Albiger, N.; Ceccato, F.; Zilio, M.; Barbot, M.; Occhi, G.; Rizzati, S.; Fassina, A.; Mantero, F.; Boscaro, M.; Iacobone, M.; et al. An analysis of different therapeutic options in patients with Cushing's syndrome due to bilateral macronodular adrenal hyperplasia: A single-centre experience. Clin. Endocrinol. 2015, 82, 808-815. [CrossRef] [PubMed]

26. Delivanis, D.A.; Athimulam, S.; Bancos, I. Modern Management of Mild Autonomous Cortisol Secretion. Clin. Pharmacol. Ther. 2019, 106, 1209-1221. [CrossRef] [PubMed]

27. Chiodini, I.; Albani, A.; Ambrogio, A.G.; Campo, M.; de Martino, M.C.; Marcelli, G.; Morelli, V.; Zampetti, B.; Colao, A.; Pivonello, R. Six controversial issues on subclinical Cushing's syndrome. Endocrine 2017, 56, 262-266. [CrossRef] [PubMed]

28. Fassnacht, M.; Dekkers, O.M.; Else, T.; Baudin, E.; Berruti, A.; de Krijger, R.R.; Haak, H.R.; Mihai, R.; Assie, G.; Terzolo, M. European society of endocrinology clinical practice guidelines on the management of adrenocortical carcinoma in adults, in collaboration with the European Network for the study of adrenal tumors. Eur. J. Endocrinol. 2018, 179, G1-G46. [CrossRef]

29. Cesareo, R.; Attanasio, R.; Caputo, M.; Castello, R.; Chiodini, I.; Falchetti, A.; Guglielmi, R.; Papini, E.; Santonati, A.; Scillitani, A.; et al. Italian Association of Clinical Endocrinologists (AME) and Italian Chapter of the American Association of Clinical Endocrinologists (AACE) Position Statement: Clinical Management of Vitamin D Deficiency in Adults. Nutrients 2018, 10, 546. [CrossRef] [PubMed]

30. Sherlock, M.; Scarsbrook, A.; Abbas, A.; Fraser, S.; Limumpornpetch, P.; Dineen, R.; Stewart, P.M. Adrenal incidentaloma. Endocr. Rev. 2020, 41, 775-820. [CrossRef]

31. Bancos, I.; Taylor, A.E.; Chortis, V.; Sitch, A.; Jenkinson, C.; Davidge-Pitts, C.J.; Lang, K.; Tsagarakis, S.; Macech, M.; Riester, A.; et al. Urine steroid metabolomics for the differential diagnosis of adrenal incidentalomas in the EURINE-ACT study: A prospective test validation study. Lancet Diabetes Endocrinol. 2020, 8, 773-781. [CrossRef]

32. Morelli, V.; Masserini, B.; Salcuni, A.S.; Eller-Vainicher, C.; Savoca, C.; Viti, R.; Coletti, F.; Guglielmi, G.; Battista, C.; Iorio, L.; et al. Subclinical Hypercortisolism: Correlation between biochemical diagnostic criteria and clinical aspects. Clin. Endocrinol. 2010, 73, 161-166. [CrossRef] [PubMed]

33. Palmieri, S.; Morelli, V.; Polledri, E.; Fustinoni, S.; Mercadante, R.; Olgiati, L.; Vainicher, C.E.; Cairoli, E.; Zhukouskaya, V.V.; Beck-Peccoz, P.; et al. The role of salivary cortisol measured by liquid chromatography-tandem mass spectrometry in the diagnosis of subclinical hypercortisolism. Eur. J. Endocrinol. 2013, 168, 289-296. [CrossRef]

34. Braun, L.T.; Riester, A.; Oßwald-Kopp, A.; Fazel, J.; Rubinstein, G.; Bidlingmaier, M.; Beuschlein, F.; Reincke, M. Toward a Diagnostic Score in Cushing's Syndrome. Front. Endocrinol. 2019, 10, 766. [CrossRef] [PubMed] 
35. Chiodini, I.; Gennari, L. Grand Challenge in Adrenal Endocrinology: Is the Legacy of the Past a Challenge for the Future of Precision Medicine? Front. Endocrinol. 2021, 12, 1-7. [CrossRef] [PubMed]

36. Nieman, L.K.; Biller, B.M.K.; Findling, J.W.; Murad, M.H.; Newell-Price, J.; Savage, M.O.; Tabarin, A. Treatment of Cushing's Syndrome: An Endocrine Society Clinical Practice Guideline. J. Clin. Endocrinol. Metab. 2015, 100, 2807-2831. [CrossRef]

37. Miller, B.S.; Auchus, R.J. Evaluation and Treatment of Patients with Hypercortisolism. JAMA Surg. 2020, 155, 1152. [CrossRef] [PubMed]

38. Perogamvros, I.; Vassiliadi, D.A.; Karapanou, O.; Botoula, E.; Tzanela, M.; Tsagarakis, S. Biochemical and clinical benefits of unilateral adrenalectomy in patients with subclinical hypercortisolism and bilateral adrenal incidentalomas. Eur. J. Endocrinol. 2015, 173, 719-725. [CrossRef]

39. Morelli, V.; Palmieri, S.; Lania, A.; Tresoldi, A.; Corbetta, S.; Cairoli, E.; Eller-Vainicher, C.; Arosio, M.; Copetti, M.; Grossi, E.; et al. Cardiovascular events in patients with mild autonomous cortisol secretion: Analysis with artificial neural networks. Eur. J. Endocrinol. 2017, 177, 73-83. [CrossRef] [PubMed]

40. Eller-Vainicher, C.; Morelli, V.; Salcuni, A.S.; Battista, C.; Torlontano, M.; Coletti, F.; Iorio, L.; Cairoli, E.; Beck-Peccoz, P.; Arosio, M.; et al. Accuracy of several parameters of hypothalamic-pituitary-adrenal axis activity in predicting before surgery the metabolic effects of the removal of an adrenal incidentaloma. Eur. J. Endocrinol. 2010, 163, 925-935. [CrossRef]

41. Oda, S.; Ashida, K.; Uchiyama, M.; Sakamoto, S.; Hasuzawa, N.; Nagayama, A.; Wang, L.; Nagata, H.; Sakamoto, R.; Kishimoto, J.; et al. An Open-label Phase I/IIa Clinical Trial of 11ß-HSD1 Inhibitor for Cushing's Syndrome and Autonomous Cortisol Secretion. J. Clin. Endocrinol. Metab. 2021, 106, e3865-e3880. [CrossRef]

42. Pivonello, R.; Ferrigno, R.; de Martino, M.C.; Simeoli, C.; Di Paola, N.; Pivonello, C.; Barba, L.; Negri, M.; de Angelis, C.; Colao, A. Medical Treatment of Cushing's Disease: An Overview of the Current and Recent Clinical Trials. Front. Endocrinol. 2020, 11, 648. [CrossRef]

43. Ferriere, A.; Tabarin, A. Cushing's syndrome: Treatment and new therapeutic approaches. Best Pract. Res. Clin. Endocrinol. Metab. 2020, 34, 101381. [CrossRef]

44. Tritos, N.A.; Biller, B.M. Advances in the Medical Treatment of Cushing Disease. Endocrinol. Metab. Clin. N. Am. 2020, 49, 401-412. [CrossRef] [PubMed]

45. Patel, Y. Somatostatin and its family of receptors. Front. Neuroendocrinol. 1999, 20, 157-198. [CrossRef] [PubMed]

46. Gatto, F.; Arvigo, M.; Amarù, J.; Campana, C.; Cocchiara, F.; Graziani, G.; Bruzzone, E.; Giusti, M.; Boschetti, M.; Ferone, D. Cell specific interaction of pasireotide: Review of preclinical studies in somatotroph and corticotroph pituitary cells. Pituitary 2018, 22, 89-99. [CrossRef] [PubMed]

47. Hofland, L.J.; van der Hoek, J.; Feelders, R.; van Aken, M.O.; van Koetsveld, P.M.; Waaijers, M.; Sprij-Mooij, D.; Bruns, C.; Weckbecker, G.; de Herder, W.W.; et al. The multi-ligand somatostatin analogue SOM230 inhibits ACTH secretion by cultured human corticotroph adenomas via somatostatin receptor type 5. Eur. J. Endocrinol. 2005, 152, 645-654. [CrossRef] [PubMed]

48. Silva, A.P.; Schoeffter, P.; Weckbecker, G.; Bruns, C.; Schmid, H.A. Regulation of CRH-induced secretion of ACTH and corticosterone by SOM230 in rats. Eur. J. Endocrinol. 2005, 153, R7-R10. [CrossRef] [PubMed]

49. Bruns, C.; Lewis, I.; Briner, U.; Meno-Tetang, G.; Weckbecker, G. SOM230: A novel somatostatin peptidomimetic with broad somatotropin release inhibiting factor (SRIF) receptor binding and a unique antisecretory profile. Eur. J. Endocrinol. 2002, 146, 707-716. [CrossRef] [PubMed]

50. Colao, A.; Petersenn, S.; Newell-Price, J.; Findling, J.W.; Boguszewski, C.; Maldonado, M.; Schoenherr, U.; Biol, D.; Mills, D.; Salgado, L.R.; et al. A 12-Month Phase 3 Study of Pasireotide in Cushing's Disease. N. Engl. J. Med. 2012, 366, 914-924. [CrossRef]

51. Pivonello, R.; Ferone, D.; de Herder, W.W.; Kros, J.M.; Caro, M.D.B.D.; Arvigo, M.; Annunziato, L.; Lombardi, G.; Colao, A.; Hofland, L.J.; et al. Dopamine Receptor Expression and Function in Corticotroph Pituitary Tumors. J. Clin. Endocrinol. Metab. 2004, 89, 2452-2462. [CrossRef] [PubMed]

52. Pivonello, R.; Arnaldi, G.; Scaroni, C.; Giordano, C.; Cannavò, S.; Iacuaniello, D.; Trementino, L.; Zilio, M.; Guarnotta, V.; Albani, A.; et al. The medical treatment with pasireotide in Cushing's disease: An Italian multicentre experience based on "real-world evidence". Endocrine 2019, 64, 657-672. [CrossRef] [PubMed]

53. Lacroix, A.; Gu, F.; Gallardo, W.; Pivonello, R.; Yu, Y.; Witek, P.; Boscaro, M.; Salvatori, R.; Yamada, M.; Tauchmanova, L.; et al. Efficacy and safety of once-monthly pasireotide in Cushing's disease: A 12 month clinical trial. Lancet Diabetes Endocrinol. 2018, 6, 17-26. [CrossRef]

54. Henry, R.R.; Ciaraldi, T.P.; Armstrong, D.; Burke, P.; Ligueros-Saylan, M.; Mudaliar, S. Hyperglycemia Associated with Pasireotide: Results from a Mechanistic Study in Healthy Volunteers. J. Clin. Endocrinol. Metab. 2013, 98, 3446-3453. [CrossRef] [PubMed]

55. Farah, J.M.; Malcolm, D.S.; Mueller, G.P. Dopaminergic inhibition of pituitary $\beta$-endorphin-like immunoreactivity secretion in the rat. Endocrinology 1982, 110, 657-659. [CrossRef] [PubMed]

56. Yin, D.; Kondo, S.; Takeuchi, J.; Morimura, T. Induction of apoptosis in murine ACTH-secreting pituitary adenoma cells by bromocriptine. FEBS Lett. 1994, 339, 73-75. [CrossRef]

57. De Bruin, C.; Hanson, J.; Meij, B.P.; Kooistra, H.S.; Waaijers, A.; Uitterlinden, P.; Lamberts, S.; Hofland, L. Expression and Functional Analysis of Dopamine Receptor Subtype 2 and Somatostatin Receptor Subtypes in Canine Cushing's Disease. Endocrinol. 2008, 149, 4357-4366. [CrossRef] [PubMed]

58. Stefaneanu, L.; Kovacs, K.; Horvath, E.; Buchfelder, M.; Fahlbusch, R.; Lancranjan, I. Dopamine D2 Receptor Gene Expression in Human Adenohypophysial Adenomas. Endocrine 2001, 14, 329-336. [CrossRef] 
59. Tateno, T.; Kato, M.; Tani, Y.; Oyama, K.; Yamada, S.; Hirata, Y. Differential Expression of Somatostatin and Dopamine Receptor Subtype Genes in Adrenocorticotropin (ACTH)-secreting Pituitary Tumors and Silent Corticotroph Adenomas. Endocr. J. 2009, 56, 579-584. [CrossRef]

60. Cooper, O.; Greenman, Y. Dopamine Agonists for Pituitary Adenomas. Front. Endocrinol. 2018, 9, 469. [CrossRef]

61. Palui, R.; Sahoo, J.; Kamalanathan, S.; Kar, S.S.; Selvarajan, S.; Durgia, H. Effect of cabergoline monotherapy in Cushing's disease: An individual participant data meta-analysis. J. Endocrinol. Investig. 2018, 41, 1445-1455. [CrossRef]

62. Matsuo, K.; Sone, M.; Honda-Kohmo, K.; Toyohara, T.; Sonoyama, T.; Taura, D.; Kojima, K.; Fukuda, Y.; Ohno, Y.; Inoue, M.; et al. Significance of dopamine D1 receptor signalling for steroidogenic differentiation of human induced pluripotent stem cells. Sci. Rep. 2017, 7, 15120. [CrossRef] [PubMed]

63. Ferriere, A.; Cortet, C.; Chanson, P.; Delemer, B.; Caron, P.; Chabre, O.; Reznik, Y.; Bertherat, J.; Rohmer, V.; Briet, C.; et al. Cabergoline for Cushing's disease: A large retrospective multicenter study. Eur. J. Endocrinol. 2017, 176, 305-314. [CrossRef] [PubMed]

64. Daniel, E.; Newell-Price, J.D.C. Therapy of endocrine disease: Steroidogenesis enzyme inhibitors in Cushing's syndrome. Eur. J. Endocrinol. 2015, 172, R263-R280. [CrossRef] [PubMed]

65. Sampath-Kumar, R.; Yu, M.; Khalil, M.; Yang, K. Metyrapone is a competitive inhibitor of $11 \beta$-hydroxysteroid dehydrogenase type 1 reductase. J. Steroid Biochem. Mol. Biol. 1997, 62, 195-199. [CrossRef]

66. Daniel, E.; Aylwin, S.; Mustafa, O.; Ball, S.; Munir, A.; Boelaert, K.; Chortis, V.; Cuthbertson, D.; Daousi, C.; Rajeev, S.P.; et al. Effectiveness of Metyrapone in Treating Cushing's Syndrome: A Retrospective Multicenter Study in 195 Patients. J. Clin. Endocrinol. Metab. 2015, 100, 4146-4154. [CrossRef]

67. Broersen, L.H.A.; Jha, M.; Biermasz, N.R.; Pereira, A.M.; Dekkers, O.M. Effectiveness of medical treatment for Cushing's syndrome: A systematic review and meta-analysis. Pituitary 2018, 21, 631-641. [CrossRef] [PubMed]

68. Feelders, R.A.; Newell-Price, J.; Pivonello, R.; Nieman, L.K.; Hofland, L.J.; Lacroix, A. Advances in the medical treatment of Cushing's syndrome. Lancet Diabetes Endocrinol. 2019, 7, 300-312. [CrossRef]

69. Verhelst, J.A.; Trainer, P.J.; Howlett, T.A.; Perry, L.; Rees, L.H.; Grossman, A.B.; Wass, J.A.H.; Sesser, G.M. Short and long-term responses to metyrapone in the medical management of 91 patients with Cushing's syndrome. Clin. Endocrinol. 1991, 35, 169-178. [CrossRef]

70. Ceccato, F.; Zilio, M.; Barbot, M.; Albiger, N.; Antonelli, G.; Plebani, M.; Watutantrige-Fernando, S.; Sabbadin, C.; Boscaro, M.; Scaroni, C. Metyrapone treatment in Cushing's syndrome: A real-life study. Endocrine 2018, 62, 701-711. [CrossRef] [PubMed]

71. Debono, M.; Harrison, R.F.; Chadarevian, R.; Gueroult, C.; Abitbol, J.-L.; Newell-Price, J. Resetting the Abnormal Circadian Cortisol Rhythm in Adrenal Incidentaloma Patients with Mild Autonomous Cortisol Secretion. J. Clin. Endocrinol. Metab. 2017, 102, 3461-3469. [CrossRef] [PubMed]

72. Puglisi, S.; Perotti, P.; Barbot, M.; Cosio, P.; Scaroni, C.; Stigliano, A.; Lardo, P.; Morelli, V.; Polledri, E.; Chiodini, I.; et al. Preoperative treatment with metyrapone in patients with Cushing's syndrome due to adrenal adenoma: A pilot prospective study. Endocr. Connect. 2018, 7, 1227-1235. [CrossRef] [PubMed]

73. Tsujimoto, Y.; Shichi, H.; Fukuoka, H.; Yamamoto, M.; Sato, I.; Imanishi, T.; Nakamura, T.; Inoshita, N.; Ishida, A.; Yamada, S.; et al. Tumor Shrinkage by Metyrapone in Cushing Disease Exhibiting Glucocorticoid-Induced Positive Feedback. J. Endocr. Soc. 2021, 5, bvab055. [CrossRef] [PubMed]

74. Ayroldi, E.; Cannarile, L.; Delfino, D.V.; Riccardi, C. A dual role for glucocorticoid-induced leucine zipper in glucocorticoid function: Tumor growth promotion or suppression? Cell Death Dis. 2018, 9, 1-12. [CrossRef] [PubMed]

75. Gatto, F.; Feelders, R.A.; van der Pas, R.; van Koetsveld, P.; Bruzzone, E.; Arvigo, M.; Dogan, F.; Lamberts, S.W.; Ferone, D.; Hofland, L. $\beta$-arrestin expression in corticotroph tumor cells is modulated by glucocorticoids. J. Endocrinol. 2020, 245, 101-113. [CrossRef]

76. Iwayama, H.; Hirase, S.; Nomura, Y.; Ito, T.; Morita, H.; Otake, K.; Okumura, A.; Takagi, J. Spontaneous adrenocorticotropic hormone $(\mathrm{ACTH})$ normalisation due to tumour regression induced by metyrapone in a patient with ectopic ACTH syndrome: Case report and literature review. BMC Endocr. Disord. 2018, 18, 19. [CrossRef]

77. De Martin, M.; Toja, P.M.; Goulene, K.; Radaelli, P.; Cavagnini, F.; Stramba-Badiale, M.; Giraldi, F.P. No Untoward Effect of Long-Term Ketoconazole Administration on Electrocardiographic QT Interval in Patients with Cushing's Disease. Basic Clin. Pharmacol. Toxicol. 2015, 118, 279-283. [CrossRef] [PubMed]

78. Oates, J.A.; Wood, A.J.; Sonino, N. The Use of Ketoconazole as an Inhibitor of Steroid Production. N. Engl. J. Med. 1987, 317, 812-818. [CrossRef]

79. Fleseriu, M.; Castinetti, F. Updates on the role of adrenal steroidogenesis inhibitors in Cushing's syndrome: A focus on novel therapies. Pituitary 2016, 19, 643-653. [CrossRef] [PubMed]

80. Stalla, G.K.; Stalla, J.; Huber, M.; Loeffler, J.-P.; Höllt, V.; Von Werder, K.; Müller, O.A. Ketoconazole Inhibits Corticotropic Cell Function in Vitro. Endocrinology 1988, 122, 618-623. [CrossRef]

81. Yan, J.Y.; Nie, X.L.; Tao, Q.M.; Zhan, S.Y.; de Zhang, Y. Ketoconazole associated hepatotoxicity: A systematic review and metaanalysis. Biomed. Environ. Sci. 2013, 26, 605-610. [CrossRef] [PubMed]

82. Tritos, N.A. Adrenally Directed Medical Therapies for Cushing Syndrome. J. Clin. Endocrinol. Metab. 2021, 106, 16-25. [CrossRef]

83. Castinetti, F.; Morange, I.; Jaquet, P.; Conte-Devolx, B.; Brue, T. Ketoconazole revisited: A preoperative or postoperative treatment in Cushing's disease. Eur. J. Endocrinol. 2008, 158, 91-99. [CrossRef] [PubMed] 
84. Castinetti, F.; Guignat, L.; Giraud, P.; Muller, M.; Kamenicky, P.; Drui, D.; Caron, P.; Luca, F.; Donadille, B.; Vantyghem, M.C.; et al. Ketoconazole in Cushing's Disease: Is It Worth a Try? J. Clin. Endocrinol. Metab. 2014, 99, 1623-1630. [CrossRef] [PubMed]

85. Comte-Perret, S.; Zanchi, A.; Gomez, F. Long-term low-dose ketoconazole treatment in bilateral macronodular adrenal hyperplasia. Endocrinol. Diabetes Metab. Case Rep. 2014, 2014, 140083. [CrossRef]

86. Novotna, A.; Krasulová, K.; Bartoňková, I.; Korhonova, M.; Bachleda, P.; Anzenbacher, P.; Dvorak, Z. Dual Effects of Ketoconazole cis-Enantiomers on CYP3A4 in Human Hepatocytes and HepG2 Cells. PLoS ONE 2014, 9, e111286. [CrossRef]

87. Blass, B.E.; Iyer, P.; Abou-Gharbia, M.; Childers, W.E.; Gordon, J.C.; Ramanjulu, M.; Morton, G.; Arumugam, P.; Boruwa, J.; Ellingboe, J.; et al. Design, synthesis, and evaluation of (2 S,4 R)-Ketoconazole sulfonamide analogs as potential treatments for Metabolic Syndrome. Bioorg. Med. Chem. Lett. 2016, 26, 5825-5829. [CrossRef] [PubMed]

88. Arakaki, R.; Welles, B. Ketoconazole enantiomer for the treatment of diabetes mellitus. Expert Opin. Investig. Drugs 2010, 19, 185-194. [CrossRef] [PubMed]

89. Schwartz, S.L.; Rendell, M.; Ahmann, A.J.; Thomas, A.; Arauz-Pacheco, C.J.; Welles, B.R. Safety Profile and Metabolic Effects of 14 Days of Treatment with DIO-902: Results of a Phase IIa Multicenter, Randomized, Double-Blind, Placebo-Controlled, Parallel-Group Trial in Patients with Type 2 Diabetes Mellitus. Clin. Ther. 2008, 30, 1081-1088. [CrossRef]

90. Eller-Vainicher, C.; Scillitani, A.; Chiodini, I. Is the hypothalamic-pituitary-adrenal axis disrupted in type 2 diabetes mellitus and is this relevant for bone health? Endocrine 2017, 58, 201-202. [CrossRef] [PubMed]

91. Chiodini, I.; Adda, G.; Scillitani, A.; Coletti, F.; Morelli, V.; Di Lembo, S.; Epaminonda, P.; Masserini, B.; Beck-Peccoz, P.; Orsi, E.; et al. Cortisol Secretion in Patients with Type 2 Diabetes: Relationship with chronic complications. Diabetes Care 2006, 30, 83-88. [CrossRef] [PubMed]

92. Morelli, V.; Aresta, C.; Gaudio, A.; Eller-Vainicher, C.; Zhukouskaya, V.V.; Merlotti, D.; Orsi, E.; Barbieri, A.M.; Fustinoni, S.; Polledri, E.; et al. Prediction of hypertension, diabetes and fractures in eucortisolemic women by measuring parameters of cortisol milieu. Endocrine 2020, 68, 411-419. [CrossRef]

93. Chiodini, I.; Gaudio, A.; Eller-Vainicher, C.; Morelli, V.; Aresta, C.; Zhukouskaya, V.V.; Merlotti, D.; Orsi, E.; Barbieri, A.M.; Fustinoni, S.; et al. Cortisol Secretion, Sensitivity, and Activity are Associated with Hypertension in Postmenopausal Eucortisolemic Women. J. Clin. Endocrinol. Metab. 2019, 104, 4441-4448. [CrossRef]

94. Pivonello, R.; Elenkova, A.; Fleseriu, M.; Feelders, R.A.; Witek, P.; Greenman, Y.; Geer, E.B.; Perotti, P.; Saiegh, L.; Cohen, F.; et al. Levoketoconazole in the Treatment of Patients with Cushing's Syndrome and Diabetes Mellitus: Results from the SONICS Phase 3 Study. Front. Endocrinol. 2021, 12, 595894. [CrossRef]

95. Geer, E.B.; Salvatori, R.; Elenkova, A.; Fleseriu, M.; Pivonello, R.; Witek, P.; Feelders, R.A.; Bex, M.; Borresen, S.W.; Puglisi, S.; et al. Levoketoconazole improves clinical signs and symptoms and patient-reported outcomes in patients with Cushing's syndrome. Pituitary 2021, 24, 104-115. [CrossRef]

96. Creemers, S.G.; Feelders, R.A.; de Jong, F.H.; Franssen, G.J.H.; de Rijke, Y.B.; van Koetsveld, P.M.; Hofland, L.J. Levoketoconazole, the 2S,4R Enantiomer of Ketoconazole, a New Steroidogenesis Inhibitor for Cushing's Syndrome Treatment. J. Clin. Endocrinol. Metab. 2021, 106, e1618-e1630. [CrossRef] [PubMed]

97. Dougherty, J.A.; Desai, D.S.; Herrera, J.B. Osilodrostat: A Novel Steroidogenesis Inhibitor to Treat Cushing's Disease. Ann. Pharmacother. 2021, 55, 1050-1060. [CrossRef]

98. Rasool, S.; Skinner, B.W. Osilodrostat for the treatment of Cushing's disease. Expert Opin. Pharmacother. 2021, 22, 1-8. [CrossRef] [PubMed]

99. Pivonello, R.; Fleseriu, M.; Newell-Price, J.; Bertagna, X.; Findling, J.; Shimatsu, A.; Gu, F.; Auchus, R.; Leelawattana, R.; Lee, E.J.; et al. Efficacy and safety of osilodrostat in patients with Cushing's disease (LINC 3): A multicentre phase III study with a double-blind, randomised withdrawal phase. Lancet Diabetes Endocrinol. 2020, 8, 748-761. [CrossRef]

100. Castinetti, F.; Amodru, V.; Brue, T. Osilodrostat in Cushing's disease: The risk of delayed adrenal insufficiency should be carefully monitored. Clin. Endocrinol. 2021. [CrossRef] [PubMed]

101. Castinetti, F.; Fassnacht, M.; Johanssen, S.; Terzolo, M.; Bouchard, P.; Chanson, P.; Cao, C.D.; Morange, I.; Pico, A.; Ouzounian, S.; et al. Merits and pitfalls of mifepristone in Cushing's syndrome. Eur. J. Endocrinol. 2009, 160, 1003-1010. [CrossRef] [PubMed]

102. Bertagna, X.; Bertagna, C.; Luton, J.-P.; Husson, J.-M.; Girard, F. The New Steroid Analog RU 486 Inhibits Glucocorticoid Action in Man. J. Clin. Endocrinol. Metab. 1984, 59, 25-28. [CrossRef]

103. Pivonello, R.; de Leo, M.; Cozzolino, A.; Colao, A. The Treatment of Cushing's Disease. Endocr. Rev. 2015, 36, 385-486. [CrossRef] [PubMed]

104. Fleseriu, M.; Biller, B.M.K.; Findling, J.W.; Molitch, M.E.; Schteingart, D.E.; Gross, C.; Auchus, R.; Bailey, T.; Carroll, T.; Colleran, K.; et al. Mifepristone, a Glucocorticoid Receptor Antagonist, Produces Clinical and Metabolic Benefits in Patients with Cushing's Syndrome. J. Clin. Endocrinol. Metab. 2012, 97, 2039-2049. [CrossRef] [PubMed]

105. Fein, H.G.; Vaughan, T.B.; Kushner, H.; Cram, D.; Nguyen, D. Sustained weight loss in patients treated with mifepristone for Cushing's syndrome: A follow-up analysis of the SEISMIC study and long-term extension. BMC Endocr. Disord. $2015,15,63$. [CrossRef] [PubMed]

106. Debono, M.; Chadarevian, R.; Eastell, R.; Ross, R.J.; Newell-Price, J. Mifepristone Reduces Insulin Resistance in Patient Volunteers with Adrenal Incidentalomas That Secrete Low Levels of Cortisol: A Pilot Study. PLoS ONE 2013, 8, e60984. [CrossRef]

107. Belokovskaya, R.; Ravikumar, A.; Arumugam, D.; Izadmehr, S.; Goddard, G.M.; Geer, E.B.; Levine, A.C. Mifepristone Treatment for Mild Autonomous Cortisol Secretion Due to Adrenal Adenomas: A Pilot Study. Endocr. Pract. 2019, 25, 846-853. [CrossRef] 
108. Cohan, P.; East, H.E.; Galati, S.-J.; Mercado, J.U.; Lim, P.J.; Lamerson, M.; Smith, J.J.; Peters, A.L.; Yuen, K.C.J. Mifepristone Treatment in Four Cases of Primary Bilateral Macronodular Adrenal Hyperplasia (BMAH). J. Clin. Endocrinol. Metab. 2019, 104, 6279-6290. [CrossRef] [PubMed]

109. Pivonello, R.; Bancos, I.; Feelders, R.A.; Kargi, A.Y.; Kerr, J.M.; Gordon, M.B.; Mariash, C.N.; Terzolo, M.; Ellison, N.; Moraitis, A.G. Relacorilant, a Selective Glucocorticoid Receptor Modulator, Induces Clinical Improvements in Patients with Cushing Syndrome: Results from A Prospective, Open-Label Phase 2 Study. Front. Endocrinol. 2021, 12, 1. [CrossRef] [PubMed]

110. Diederich, S.; Grossmann, C.; Hanke, B.; Quinkler, M.; Herrmann, M.; Bähr, V.; Oelkers, W. In the search for specific inhibitors of human 11b-hydroxysteroid-dehydrogenases (11b-HSDs): Chenodeoxycholic acid selectively inhibits 11b-HSD-I. Eur. J. Endocrinol. 2020, 142, 200-207.

111. Rosenstock, J.; Banarer, S.; Fonseca, V.A.; Inzucchi, S.E.; Sun, W.; Yao, W.; Hollis, G.; Flores, R.; Levy, R.; Williams, W.V.; et al. The 11- -Hydroxysteroid Dehydrogenase Type 1 Inhibitor INCB13739 Improves Hyperglycemia in Patients with Type 2 Diabetes Inadequately Controlled by Metformin Monotherapy. Diabetes Care 2010, 33, 1516-1522. [CrossRef] [PubMed] 